\title{
Color and Contrast Sensitivity in the Lateral Geniculate Body and Primary Visual Cortex of the Macaque Monkey
}

\author{
David H. Hubel and Margaret S. Livingstone \\ Department of Neurobiology, Harvard Medical School, Boston, Massachusetts 02115
}

\begin{abstract}
We tested color and contrast sensitivity in the magnocellular and parvocellular subdivisions of the lateral geniculate body and in layers $2,3,4 \mathrm{~B}$, and $4 \mathrm{C} \alpha$ of visual area 1 to obtain physiological data on the degree of segregation of the 2 pathways and on the fate of the color and contrast information as it is transmitted from the geniculate to the cortex. On average, magnocellular geniculate cells were much less responsive than parvocellular cells to shifts between 2 equiluminant colors. Nevertheless, many magnocellular cells (though not all) continued to give some response at equiluminance. As expected from previous studies, luminance contrast sensitivity differed markedly between magnocellular and parvocellular layers.
\end{abstract}

In V-1, the properties of cells in the magnorecipient layers 4C $\alpha$ and 4B faithfully reflected the properties of magnocellular geniculate cells, showing no evidence of any parvocellular input. Like magnocellular geniculate cells, they showed high contrast sensitivity, and with color contrast stimuli they showed large response decrements at equiluminance. In the interblob regions of cortical layers 2 and 3 , which anatomically appear to receive most of their inputs from parvorecipient layer $4 C \beta$, contrast sensitivities of some of the cells were compatible with a predominantly parvocellular input. Other interblob cells had sensitivities intermediate between magno- and parvocellular geniculate cells, suggesting a possible contribution from the magnocellular system. Many cells in cortical layers 2 and 3 responded to color-contrast borders equally well at all relative brightnesses of the 2 colors, including equiluminance.

We recorded from many direction- and disparity-selective cells in V-1: most of the direction-selective and all of the clearly stereo-selective cells were located in layer 4B.

The primate retinogeniculate pathway is subdivided into at least 2 parallel channels, the A-cell magnocellular and the B-cell $\Rightarrow$ parvocellular pathways. Anatomical evidence indicates that these subdivisions remain largely segregated, from the retina to higher cortical visual areas. Type A retinal ganglion cells project

\footnotetext{
Received May 24, 1989; revised Jan. 22, 1990; accepted Feb. 6, 1990.

Visual stimuli were programmed by David Freeman. Histological examination was done by Janet Robbins. The work was supported by NIH grant EY00605, Office of Naval Research Grant N00014 88 K 0200, and a Presidential Young Investigator Award from the NSF. We are grateful for comments from Richard Born, Roger Tootell, and an anonymous referee.

Correspondence should be addressed to Margaret Livingstone, Department of Neurobiology, B-453, 220 Longwood Avenue, Harvard Medical School, Boston, MA 02115.

Copyright (C) 1990 Society for Neuroscience $0270-6474 / 90 / 072223-15 \$ 03.00 / 0$
}

to the magnocellular geniculate layers, which in turn project to layer $4 \mathrm{C} \alpha$ of the striate cortex $(\mathrm{V}-1)$; type $\mathrm{B}$ ganglion cells project to the parvocellular layers, which project to layers $4 \mathrm{C} \beta$ and $4 \mathrm{~A}$ of V-1 (Hubel and Wiesel, 1972; Lund et al., 1975; Leventhal et al., 1981). From Golgi and horseradish-peroxidase studies, Lund (1973), Lund and Boothe (1975), and Fitzpatrick et al. (1985) determined that magnorecipient layer $4 \mathrm{C} \alpha$ projects to layer $4 \mathrm{~B}$, which in turn projects to visual area 2 and to MT, and parvorecipient layer $4 C \beta$ projects to layers 2 and 3 and from there to visual area 2 ; both $4 \mathrm{C} \alpha$ and $4 \mathrm{C} \beta$ also send less dense projections to the deeper layers. There is some evidence that color-opponent center-only (Type 2) cells are found in or near the parvocellular interlaminar leaflets in the geniculate and project directly to the blobs of the upper layers of V-1 (Livingstone and Hubel, 1982, 1984, and unpublished observations; Fitzpatrick et al., 1983). There may thus be a third geniculocortical subdivision, specifically concerned with color information. Recent evidence seems to indicate that the blobs also receive projections from layer $4 \mathrm{C} \beta$ (Michael, 1988).

Physiological differences suggest that the magno and parvo subdivisions are responsible for different aspects of visual perception. In the geniculate, the 2 subdivisions differ in their (1) color selectivity, (2) temporal characteristics, (3) contrast sensitivity, and (4) spatial resolution. Thus most parvocellular geniculate cells are color selective and have low contrast sensitivity, whereas magnocellular cells are generally not color selective and have higher contrast sensitivity. Several stages further on, at the level of cortical areas V-2 and MT, cells receiving input from the magno system show movement-direction selectivity or disparity selectivity or both, whereas the responses of cells receiving input mainly from the parvo system suggest an involvement in color or form perception. Movement perception and stereoscopic depth perception should therefore be magnolike when tested for the 4 variables listed above, whereas form and color perception should be parvo-like. Tests of human perception bear out these predictions to a remarkable degree (for references, see Livingstone and Hubel, 1987b). For example, stereopsis and motion perception both deteriorate with stimuli that have color contrast but no luminance contrast (equiluminant stimuli), and they both show high contrast sensitivity, whereas high-resolution form perception has lower contrast sensitivity and is only slightly diminished for equiluminant images.

Although many perceptual, anatomical, and physiological studies suggest that the magno and parvo pathways remain largely separate, some opportunities for cross-talk do exist. Anatomically, the magnocellular and parvocellular inputs to $\mathrm{V}-1$ are almost completely segregated in layer $4 \mathrm{C}$ (Hubel and Wiesel, 
1972; Hendrickson et al., 1978; Blasdel and Lund, 1983), but some intrinsic neurons of each sublamina extend processes into the other (Lund, 1987). Processes of some 4C $\alpha$ and some 4B cells extend into layer 3 (Lund and Boothe, 1975; Fitzpatrick et al., 1985). Malpeli et al. (1981) recorded from cortical cells during reversible inactivation of different layers of the geniculate and concluded that orientation-selective cells in $\mathrm{V}-1$ can receive both magno- and parvocellular input.

In the present study, we used physiological tests of color and contrast sensitivity to investigate the degree to which the magno and parvo systems remain separate in $\mathrm{V}-1$. We had 2 reasons for starting this study in the geniculate, even though color and contrast sensitivity have been the subject of several previous geniculate studies. First, there is disagreement over the degree to which magnocellular geniculate cells respond to equiluminant color-contrast stimuli. Some studies have found that parvocellular geniculate cells respond more strongly than magnocellular cells to color contrast (Krüger, 1979; Hicks et al., 1983; Derrington et al., 1984), but others (Schiller and Colby, 1983; Hurlbert et al., 1987; Logothetis et al., 1990) reach just the opposite conclusion. It seemed important to try to understand the discrepancies. Second, we wished to test geniculate cells with the kinds of stimuli that we found to be useful at more central levels and in psychophysical experiments. In the geniculate, most physiological studies on color and contrast sensitivity have used sinewave stimuli, often without also categorizing the cells according to responses to colored and white spots. We wished to use spots and bars, in addition to sinewave gratings, because in the cortex single lines with sharp borders are always as effective as sinewave gratings, and often far more so (Born and Tootell, 1989). Finally, we thought that gratings would be especially inappropriate for cells in visual area 2 , which we plan to study next, because many $\mathrm{V}$-2 cells are end-stopped, and many are sharply tuned for binocular disparity.

\section{Materials and Methods}

\section{Animal preparation}

We recorded single-unit responses to visual stimuli from the lateral geniculate body and visual area 1 (V-1 or striate cortex) in 26 Macaca fascicularis monkeys. In these acute experiments the animals were surgically anesthetized throughout the experiment. A monkey was first injected, while in its cage, with an intramuscular dose of ketamine (15 $\mathrm{mg} / \mathrm{kg}$ ). From then until the end of the experiment, when it was killed by an overdose of pentothal, the animal was surgically anesthetized and should have experienced no pain or discomfort. A $2 \%$ haluthane-in-air mixture was used as an inhalation anesthetic for preparation for recording. The anesthetic level in these surgical phases of the experiment was deep enough that no movements were elicited in the unparalyzed animal when incisions were made. Before making incisions or placing the animal in the head holder, the sites of incision and pressure points were infiltrated with long-lasting local anesthetic (Marcaine). We inserted an intravenous cannula and a tracheotomy tube, placed the head in a stereotaxic holder, made a scalp incision, drilled a small hole in the skull, cut a small hole in the dura, keeping the arachnoid intact, and attached the electrode advancer.

When we were ready to record, we began administration of a paralyzing agent (intravenous gallamine, $10 \mathrm{mg} / \mathrm{kg}$, then $10 \mathrm{mg} / \mathrm{kg} / \mathrm{hr}$ ) and changed the inhalation anesthetic from halothane to a $75-80 \%$ nitrous oxide $/ 20-25 \%$ oxygen mixture supplemented with $2-8 \mu \mathrm{g} / \mathrm{kg} / \mathrm{hr}$ sufentanil. To insure adequate anesthesia we monitored the state of the animal with an EEG recorded from electrodes on the scalp or skull, watching for any periods of desynchronization that might suggest arousal, and with an ECG, to indicate tachycardia. The monkey's pupils were dilated with homatropine and the eyes fitted with contact lenses to focus them at $1.5 \mathrm{~m}$ distance. The relative positions of the 2 foveas were determined with a reversing ophthalmoscope.

\section{Physiological recording}

For recording, the head was held in a stereotaxic holder that leaves the visual fields largely unobstructed. We recorded single units extracellularly using electropolished tungsten wires insulated with a clear vinyl lacquer (Hubel, 1959). The electrode was hydraulically advanced through a 16 gauge stainless steel guard tube. We positioned the guard tube over the hole, placed vaseline around the hole, covered it with a rubber gasket, and, to minimize pulsations, sealed the whole assembly to the skull with dental impression compound. We located the lateral geniculate body by stereotaxic coordinates and made vertical penetrations in which we isolated single units approximately every $50 \mu \mathrm{m}$. The receptive fields in the different penetrations varied from $3^{\circ}$ to $20^{\circ}$ eccentricity. Penetrations into visual area 1 were positioned at $5^{\circ}-10^{\circ}$ eccentricity. The electrode was aimed from anterior to posterior at a shallow angle to the surface $\left(10^{\circ}-35^{\circ}\right)$, and we isolated single units on average every $50 \mu \mathrm{m}$. We examined cells in layers $2,3,4 \mathrm{~A}, 4 \mathrm{~B}$, and $4 \mathrm{C} \alpha$ but did not study cells in layer $4 \mathrm{C} \beta$ since the electrodes that were optimal for obtaining stable single-unit recordings in the upper layers were too coarse to get good isolation of single units in $4 \mathrm{C} \beta$.

To correlate the physiological properties of cells with their anatomical localization we made small ( $2 \mu \mathrm{A}, 2 \mathrm{sec})$ electrolytic lesions at intervals during the recording (Hubel, 1959). We usually recorded from the region at which we planned to make a lesion, went farther forward to study the cells just beyond that region, then retracted the electrode back to the original position and checked the physiological properties again before making the lesion. Our accuracy in reconstructing the electrode position was determined by the accuracy of this procedure and the size of the lesions, which were between 100 and $150 \mu \mathrm{m}$ in diameter. No cells were included in this study whose location could not be clearly determined histologically.

\section{Visual stimuli}

By using a slide projector, tangent screen, and interference filters, we initially categorized each cell into the major commonly recognized subtypes (Types $1-4$ for geniculate cells; simple, complex, or unoriented for cells in V-1). Following this, the measurements that form the bulk of our results were made with TV-monitor techniques because of the ease of controlling stimulus size, shape, and motion, and of generating a shape of one color on a background of another. These advantages far outweighed any drawbacks of the broad and irregular spectral emissions of the TV-monitor phosphors and the somewhat limited range of colors available.

In our projection system, the light source was a $500 \mathrm{~W}$ tungsten bulb, and the interference filters were $10 \mathrm{~nm}$ bandwidth in $10 \mathrm{~nm}$ steps (Ewing). For rough checks as to whether cortical cells were color coded, it was convenient to use a set of 4 broad-band gelatin filters, red, green, blue, and yellow

The color graphics system consisted of a Trinitron color monitor ( $\mathrm{P} 22$ phosphors) and computer graphics equipment (Silicon Graphics Iris 3030 system). The monitor was selected, after trying several other manufacturers, on the basis of the independence of beam intensity and spot size or position. Stimuli were initiated and spikes counted by a microprocessor and a Hewlett Packard 9826 computer. The stimuli consisted of moving or stationary spots or bars of variable size. The refresh rate of $60 \mathrm{~Hz}$ (without interlace) placed an upper limit on speed of movement and Hicker. A few magnocellular cells gave audible rhythmic entrainment at $60 \mathrm{~Hz}$, but this is unlikely to have had any effect on our results.

Calibration of the TV monitor. We first measured the relative energy at each of the 255 gun levels, for each of the 3 phosphors, assigning energy values of 1000 to gun settings of 255 , adjusted so that the 3 in combination gave a white $\left(55 \mathrm{Cd} / \mathrm{m}^{2}\right)$. The calibration was made with a Prichard spot photometer (Sp-1980a CD). These energy values were incorporated into computer look-up tables.

Next we measured, in absolute values, the spectral emission curves of each of the color guns, set at 255. Spectral peaks are given in Table 1. Measurements were made over a $400-700 \mathrm{~nm}$ spectral range, in 5 $\mathrm{nm}$ steps for the green and blue guns and in $1 \mathrm{~nm}$ steps for the red. The results, when integrated with the 3 spectra $\bar{x}, \bar{y}$, and $\bar{z}$, yield the tristimulus values for each of the phosphors (Table 1). We are indebted to Michael Burns and Robert Savoy of the Rowland Foundation for their help in these calibrations.

In the first few experiments we determined the cone inputs to each geniculate cell using interference filters as described by Wiesel and Hubel (1966). In later experiments, we supplemented these observations by 
generating small and large spots designed to change the stimulus level of one type of cone without influencing the other two. To do this (again with the help of Michael Burns and Robert Savoy), we first computed the phosphor tristimulus values as described above. We then used a 3 $\times 3$ matrix prepared by Smith and Pokorny (1986) to convert from $X$, $Y$, and $Z$ tristimulus values of any light to human cone excitations, to give a $3 \times 3$ matrix that would transform phosphor settings to cone excitations. The reverse transformation, from cone excitations to phosphor energies, thus involved inverting this $3 \times 3$ matrix, after normalizing according to a convention that assumes that with all 3 guns set at 255 , the white screen excites the 3 cone systems equally.

The matrices obtained were as follows:

and

$$
\begin{gathered}
\mathrm{L} \\
\mathrm{M} \\
\mathrm{S}
\end{gathered}=\left(\begin{array}{lll}
0.293 & 0.603 & 0.104 \\
0.134 & 0.704 & 0.162 \\
0.046 & 0.099 & 0.854
\end{array}\right) \times \begin{array}{r}
\mathbf{R} \\
\mathrm{B}
\end{array}
$$

$$
\begin{aligned}
& \mathrm{R} \\
& \mathrm{B}
\end{aligned}=\left(\begin{array}{rrr}
5.60 & -4.83 & 0.23 \\
-1.02 & 2.34 & -0.32 \\
-0.18 & -0.01 & 1.19
\end{array}\right) \times \mathrm{L}
$$

where $\mathrm{R}, \mathrm{G}$, and $\mathrm{B}$ refer to phosphor energies as defined above, and $\mathrm{L}$, $M$ and $S$ refer to activations of the long-, middle-, and short-wavelength cones according to a convention that assigns activation values of 1000 , 1000,1000 for our maximum white stimulus.

These calculations assume that cone excitation curves are similar for humans and macaque monkeys (De Valois et al., 1974; Nunn et al., 1984). We programmed our system so that we could set a spot to a specific gray level and then change it so as to give a higher or lower stimulation to one cone type without changing the stimulation to the other two. The range over which we could change the stimulation of each cone was, of course, limited by the impossibility of obtaining phosphor settings less than zero or greater than 255 .

Our categorizations of Type 1 geniculate cells by the 2 methods, projectors and filters versus single-cone stimulation, always agreed. Tests of this single-cone stimulation procedure on 2 gentlemen, one protanope and one deuteranope, make us confident of its validity in humans, at least for the red and green cones.

\section{Single-cell studies}

Color-contrast curves. For each geniculate cell we generated color-contrast sensitivity curves using just the red and green phosphors of the monitor. On the monitor screen diffusely lit with a constant green phosphor setting (energies, not gun settings) of red $=0$, green $=50$, blue $=$ 0 , a red spot of field-center size or smaller and of variable intensity appeared (red $=0-300$, green $=0$, blue $=0$ ), and one second later changed back to green. We plotted the responses for green-to-red and red-to-green as a function of red intensity. Receptive-field centers were first mapped with spots much smaller than the size of the field centers. The stimulus cycle was repeated once every $6 \mathrm{sec}$, and responses averaged for a fixed period, usually the first $250 \mathrm{msec}$, after each change in color. For humans, as judged by flicker photometry, the green phosphor at an energy of 50 was equiluminant with a red phosphor energy of 150 . We also used moving red/green edges and bars, with essentially identical results.

In the cortex, to obtain comparable color-contrast sensitivity curves we used a moving red bar of optimum orientation, speed, and size, and varied the red energy of the bar against a constant green background (red $=0$, green $=50$, blue $=0$ ). We also used sinewave gratings to compare the results with those obtained with bars, and especially to rule out the possibility that our results were distorted by artifactual luminous-contrast borders produced by chromatic aberration. The gratings were $1 \mathrm{cycle} / \mathrm{deg}$, generated by varying the green phosphor energy sinusoidally from an energy of 4 to an energy of 50 , while the red phosphor energy was varied sinusoidally, $180^{\circ}$ out of phase with the green, from a minimum of 4 to a maximum that varied from 4 to 300 . The gratings covered the entire activating part of the receptive field of the cell, and the best responses were obtaincd if the gratings did not extend beyond this region. The gratings were set at the optimum orientation and moved across the receptive field at a speed of 1,2 , or 3 cycles/sec, whichever gave the best response.

Contrast sensitivity. To measure contrast sensitivity in geniculate cells we turned on and off a gray spot, the same size as the receptive-field
Table 1. Color monitor phosphor characteristics

\begin{tabular}{llll} 
Color & $\begin{array}{l}\text { Wavelength } \\
\text { at peak } \\
\text { energy } \\
(\mathrm{nm})\end{array}$ & \multicolumn{2}{l}{$\begin{array}{l}\text { CIE chromaticity } \\
\text { coordinates }\end{array}$} \\
\cline { 2 - 4 } Red & 630 & $x$ & $y$ \\
Green & 525 & 0.61 & 0.35 \\
Blue & 445 & 0.31 & 0.59 \\
\hline
\end{tabular}

center or smaller, against a constant gray background (red $=$ green $=$ blue $=20$ ) and measured the response in spikes/sec as a function of the brightness of the spot. In the cortex we used a moving gray bar, of optimum orientation, speed, and size, and varied the brightness, against a constant gray background (all 3 phosphors $=20$ ).

To measure disparity tuning we used 2 bars, both at the optimum orientation moving synchronously across the receptive fields of the 2 eyes, which, because of slight divergence of the optic axes, were usually not superimposed. At zero disparity the sweep of each bar was centered on the receptive field of one eye. Then, keeping the center position of one bar's sweep constant, we varied the position of sweep of the other bar, perpendicular to its oricntation, and measured the cell's response as a function of this displacement.

The error bars in each graph represent standard error of the mean. All stimuli were presented in pseudorandom order.

\section{Histology}

At the end of each experiment we injected a lethal intravenous dose of sodium pentothal and perfused the animal through the heart with saline followed by fixative $(2.25 \%$ glutaraldehyde, $0.75 \%$ formaldehyde, $0.9 \%$ $\mathrm{NaCl}, 0.1 \mathrm{M}$ sodium phosphate, $\mathrm{pH} 7.5$ ). We removed the brain, froze the lateral geniculate bodies or the flattened posterior occipital cortex in liquid Freon 22 at $-30^{\circ} \mathrm{C}$, cut sections at $50-100 \mu \mathrm{m}$ thickness, and stained them for cytochrome oxidase (Wong-Riley, 1979). The small electrolytic lesions made during recording sessions were easily visible in the cytochrome oxidase-stained sections and allowed us to correlate the physiological properties of cells along the electrode penetrations with their laminar positions.

\section{Results}

\section{Color sensitivity}

\section{Lateral geniculate body}

We measured the responses of cells in the lateral geniculate to a spot of field-center size as it changed from green to red and from red back to green. The green was kept constant, while the brightness of the red was varied. For a broad-band on-center cell, the response in going from green to red (filled circles in our figures) of course increased as the red brightness increased, and the red-to-green responses (open squares) decreased. The reverse was seen in off-center cells.

For all the magnocellular geniculate cells we studied, the 2 response curves (green-to-red and red-to-green) crossed at or near the human equiluminance point $($ red $=150 /$ green $=50$ ). (The heights of the on- and off-response curves and hence the exact point of their crossing were to some extent dependent on the intervals over which impulses were counted.) Many magnocellular cells gave no response at the point of crossing (Fig. $1 A$ ), but some continued to respond at all red/green ratios (Fig. $1 B$ ), giving a discharge both at red-to-green and green-to-red. In these cells the response at both transitions made it clear that we had not simply missed the particular color ratio needed to obtain a null. The lack of complete mutual cancellation means that these cells cannot simply be summing red and green cone inputs in a linear fashion. Such a response doubling was first described by Schiller and Colby (1983). Lee et al. (1989) found 

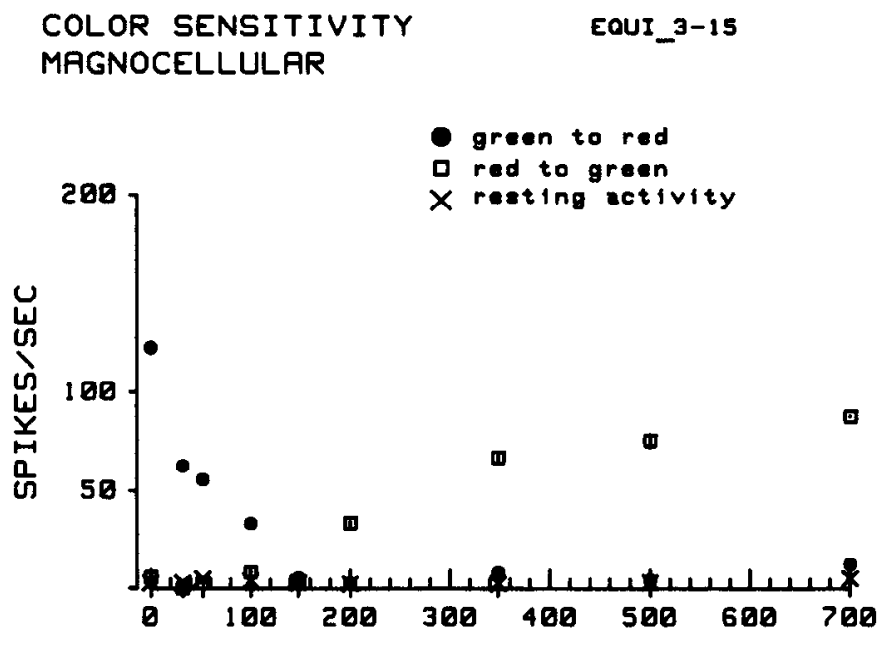

A

RED ENERGY (GREEN=50)
EOUI_3-20

MAGNOCELLULAR GENICULATE BROAD BAND ON CENTER

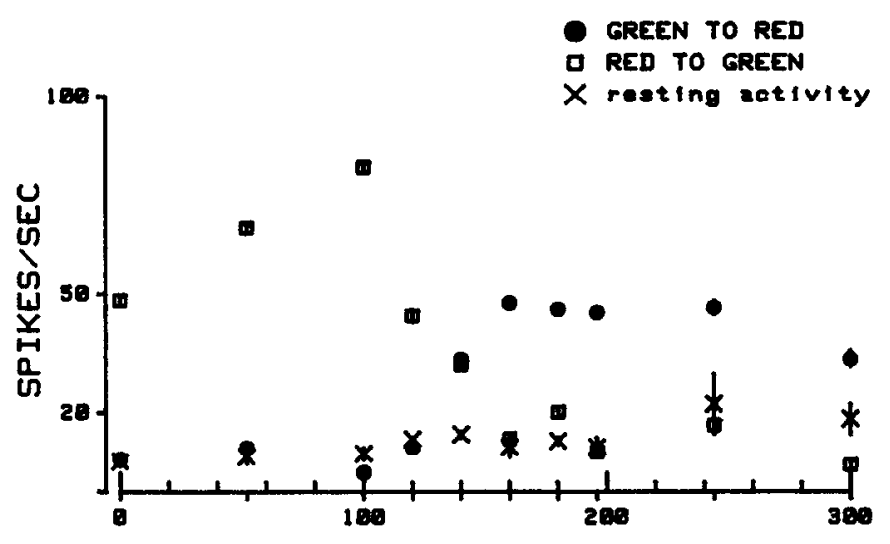

B

RED ENERGY (GREEN=50)

\section{COLOR SENSITIVITY MAGNOCELLULRR}

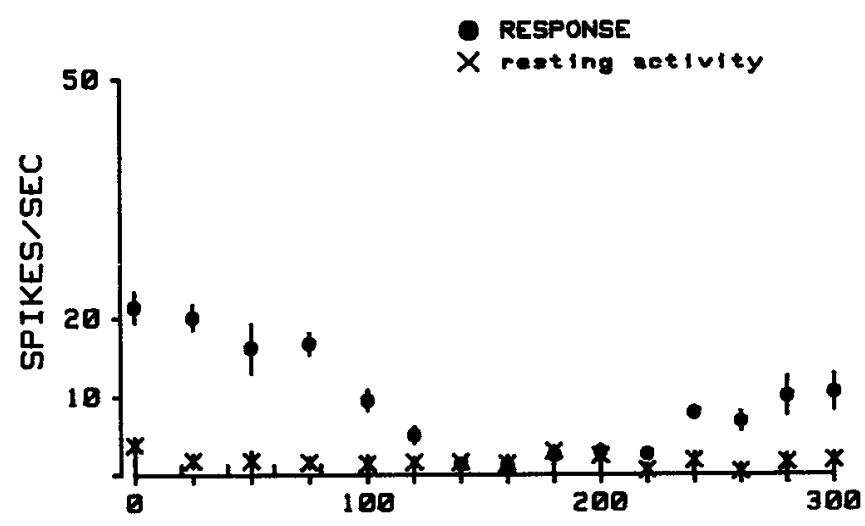

\section{RED ENERGY (GREEN=58)}

Figure 1. $A$ and $B$, Responses of 2 magnocellular neurons to changing a $1 / 2^{\circ}$ green spot to red for $1 \mathrm{sec}$ and then back to green. There were 6 sec between stimuli, during which time the spot was continuously green; "resting activity" indicates the firing rate to a static green spot for the that it occurred only when both the receptive-field center and surround were stimulated, indicating a nonlinearity in the center-surround interaction. Our stimuli were confined to the field centers as mapped with very small spots, but we cannot rule out invasion of the surround system if the surround extends into the field centers. In any case, all the magnocellular cells we studied showed marked decreases in their responses at or near human equiluminance (red $=150 /$ green -50 ), the average response at equiluminance being $20 \%( \pm 0.12 \% \mathrm{SD})$ of the maximum response. Magnocellular neurons showed similar decrements in response at equiluminance when we used a moving red bar on a green background as the stimulus (Fig. 1C).

Parvocellular geniculate cells, falling as they do into 3 classesType 1, with field centers fed by cones of a single class; Type 2, with opponent color centers and no surround; and Type 3, with broad-band centers - would hardly be expected to behave in a uniform way to color-contrast stimuli. They showed response nulls or decrements that occurred over a wide span of $\mathrm{red} /$ green intensity ratios, and the red/green ratio that gave the minimum response correlated well with their center-type.

Type 1 cells with red-cone inputs to their centers, either onor off-center, showed response minima at red/green ratios lower than red $=150 /$ green $=50$; green-center cells showed minima at higher red/green ratios. For example, the red-on center/greenoff surround cell shown in Fig. $2 A$ had a response minimum around a ratio red $=90 /$ green $=50$; the red off-center/green onsurround Type 1 cell in Figure $2 B$ had a minimum at red $=$ $100 /$ green $=50 ;$ and the green-on center $/$ red-off surround cell in Figure $2 C$ had a minimum at red $=200 /$ green $=50$. The broadband on-center (Type 3 ) cell in Figure $2 D$ had a minimum at red $=170$ green $=50$, a ratio slightly higher than the human equiluminance point.

The red/green ratios giving the minimum response for all the magno- and parvocellular units so far studied are shown in Figure 3. The magnocellular units were tightly clustered at a $\mathrm{red} /$ green ratio close to the human equiluminance point, whereas the parvocellular units, even the broad-band ones, had a wider range of null points. From the action spectra of the phosphors and the absorption characteristics of the 3 cone types, it should be possible to predict the relative red/green phosphor energies for equal activation of any given cone type. The first $3 \times 3$ matrix (see Materials and Methods) predicts a red/green phosphor energy ratio of 2.06 for the red (S) cone and 5.25 for the green $(\mathrm{M})$; so that for a green phosphor setting of 50 , the nulls of the red-center cells should occur at a red phosphor energy of 103 , and the nulls of the green-center cells should be at a red energy of 263. The null points of the red-center and green-center Type 1 cells do cluster loosely around these values. Some of the variability in the null points may be due to differences in the intervals over which the responses were averaged or how strong-

1 sccond interval beforc cach stimulus. The background was black, the green was kept constant at 50, and the brightness of the red varied (red $=0-300$, green $=0$, blue $=0$ ). Average human equiluminance as measured by flicker photometry is at red $=150$. The cell in $(A)$ was a broadband off-center cell, and the cell in $(B)$ was a Type 4 on-center cell; both cells had receptive fields $15^{\circ}$ from the fovea. The cell in $C$ was a magnocellular broad-band on-center cell $10^{\circ}$ from the fovea. The stimulus was a red bar that moved across the cell's receptive field on a green background. The brightness of the red bar was varied from 0 to 300 , while the green background was kept constant at 50. Five to ten responses were averaged for each point. 


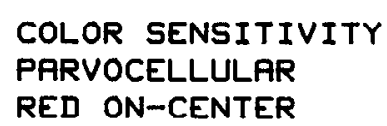

RED ON-CENTER

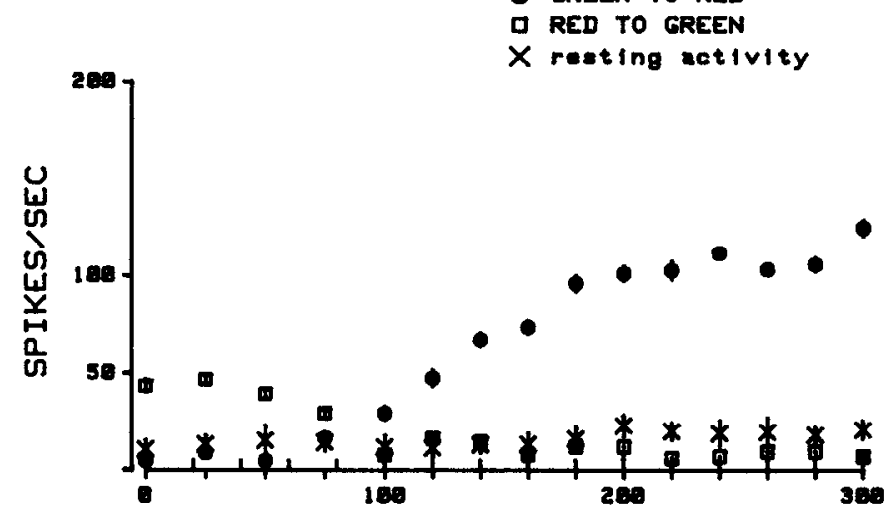

A

RED ENERGY (GREEN=50)

EOUI_19-26

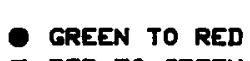

REn to cren

$X$ resting activity

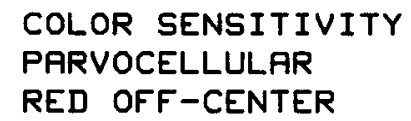

EOUI_37-16

RED OFF-CENTER

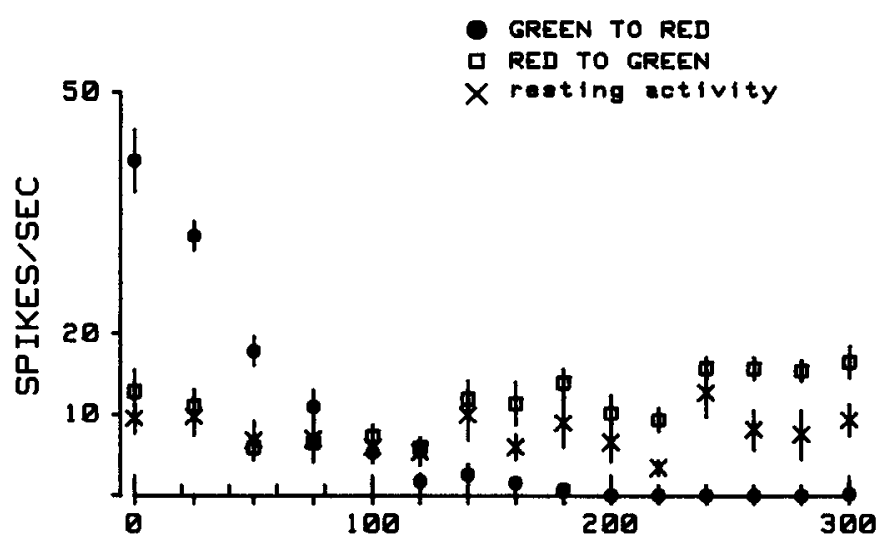

B

RED ENERGY (GREEN=50) COLOR SENSITIVITY
PARVOCELLULAR

EOUI_28-14
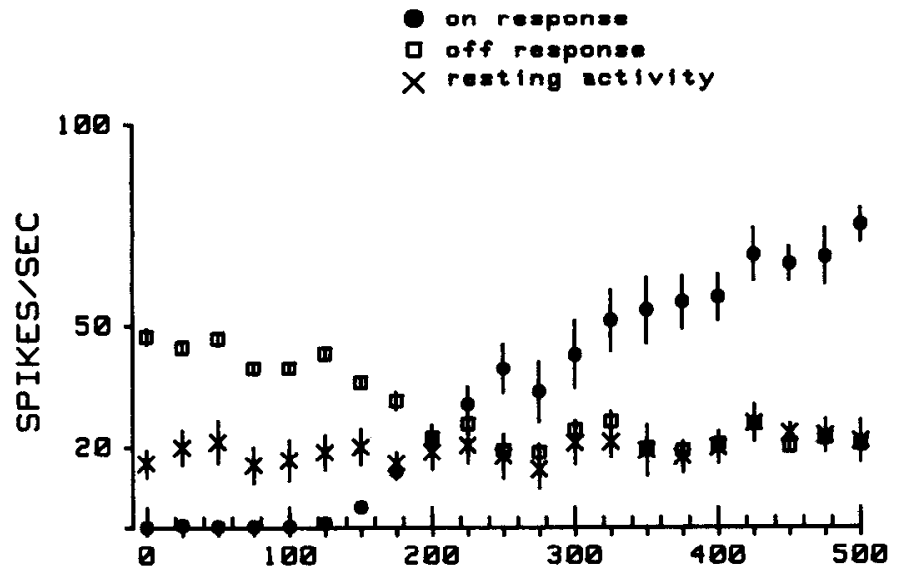

C

RED ENERGY (GREEN=5D)

\section{COLOR SENSITIVITY \\ PARVOCELLULAR \\ BROAD BAND ON-CENTER}

EQUI_38-17

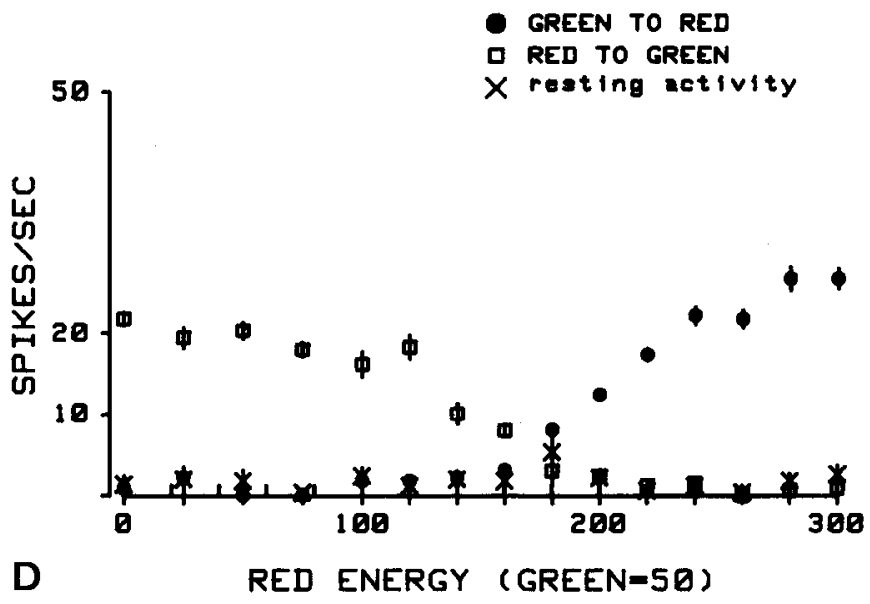

Figure 2. Responses of 4 parvocellular neurons to the same stimulus as described for Figure $1 A, B$. Five to ten responses were averaged for each point. The cell in $A$ was a red-on center/green-off surround cell in layer 6 of the geniculate. The cell's receptive field center was $0.2^{\circ}$ in diameter, $16^{\circ}$ from the fovea, and the stimulus spot was $0.2^{\circ}$. The cell in $B$ was a red off-center cell in geniculate layer 6 at $20^{\circ}$ eccentricity; the stimulus size and the cell's receptive field center were $0.3^{\circ}$ in diameter. The cell in $C$ was a green-on center/red-off surround cell in layer 6 . The receptive field was $15^{\circ}$ in eccentricity, and the field center and the stimulus were both $0.25^{\circ}$. The cell in $C$ was an on-center broadband cell in layer 5 of the geniculate. The cell's receptive field was $15^{\circ}$ from the fovea, the field center and the stimulus spot were $0.25^{\circ}$. The cell in $D$ was an on-center broadband cell in layer 5 of the geniculate, $20^{\circ}$ from the fovea. The field center and stimulus spot were $0.75^{\circ}$ in diameter.

ly our center-sized stimuli also activated the surround mechanism, either because of the presence of surround influence within the receptive-field center or because some of our stimuli may have extended into the surround.

\section{Visual area 1}

To assess color selectivity in cortical cells, we measured the cell's response to a moving red bar of variable brightness on a constant green background. The bars were of optimum orientation, size, and speed of movement, and we stimulated the receptive field of the dominant eye only (unless the cell responded only to binocular stimuli, in which case we stimulated the 2 eyes together at the optimum disparity).
As Gouras and Krüger have pointed out (1979), to use this method to determine whether a cell is unresponsive to chromatic borders at some relative brightness of the colors, the cell must respond to both white bars on a dark background and dark bars on a light background. The great majority of the cells we recorded from did respond well to both dark and light bars. A few cells failed to respond to dark bars, and a few to light bars. Figure $4 A$ shows an example of a cell that responded well to dark bars but not to light ones, either to white or to any monochromatic wavelength. Figure $4 B$ shows a cell that responded better to light bars than to dark ones. In tangential penetrations, cells that responded only to dark bars or only to light bars tended to occur in clusters. We often found such sign-selective cells at 


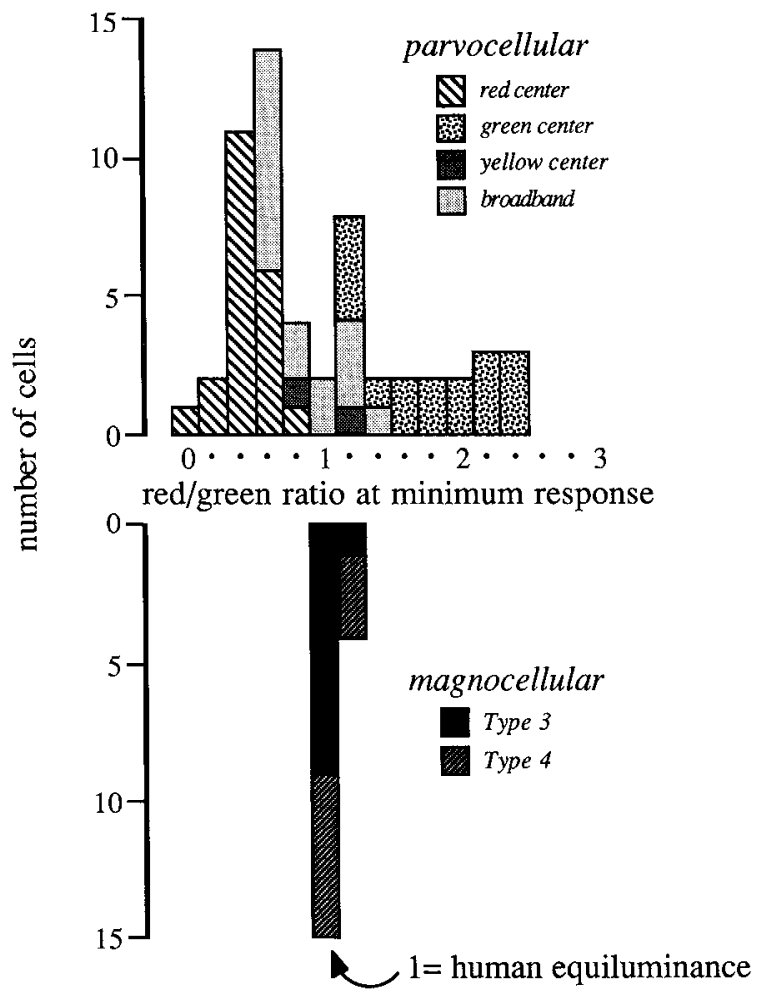

Figure 3. Red-green ratio, normalized to human equiluminance, at minimum response for magno- and parvocellular geniculate cells, from graphs such as those in Figures 1 and 2. From the cone absorption curves and the emission spectra of the phosphors we can calculate that red cones should be equally excited by the red and green phosphors when the red phosphor is set at 103 and the green at 50. Normalized to human equiluminance ( $\mathrm{red}=150 /$ green $=50$ ), this would be a red $/$ green ratio of 0.69 . The green cones should be equally stimulated by a ratio of red $=263 /$ green $=50$, or a normalized ratio of 1.75 .

the edges of blobs in layers 2 and 3 or directly under blobs in layers $4 \mathrm{~B}$ and $4 \mathrm{C} \alpha$.

Cells in magnorecipient layers $4 \mathrm{~B}$ and $4 \mathrm{C} \alpha$ were similar to magnocellular geniculate cells in their color selectivities, having a marked decrease in response at or near equiluminance. For example, the layer $4 \mathrm{~B}$ cells shown in Figure 5 responded well to a red bar on a green background when the bar was either lighter or darker than the background, but far less well when the red/green ratio was close to the human equiluminance point (red $=150$ ). Every layer 4B cell showed at least a 50\% decrease in response at equiluminance, and many showed no response at all (Fig. 5, $A, B$ ). For the 56 cells tested in layers $4 \mathrm{~B}$ and $4 \mathrm{C} \alpha$, the average ratio of response at equiluminance to maximum response was 0.12 (standard deviation $(\mathrm{SD})=0.11$ ), a ratio even lower than the value of 0.20 obtained in the geniculate.

Cells in the interblob regions of layers 2 and 3 were orientation-selective, and most were complex. Some showed deep minima near equiluminance, but many showed no response minimum or had only a shallow dip that was often not at equiluminance (Fig. 6).

Figure 7 shows the responses at equiluminance, as a fraction of the maximum response, for cells at various depths from the surface, for each cell studied in 17 penetrations in $\mathrm{V}-1$. The average fractional response at equiluminance of the 141 interblob cells we tested was $0.41 \pm 0.22$ (SD), a value considerably
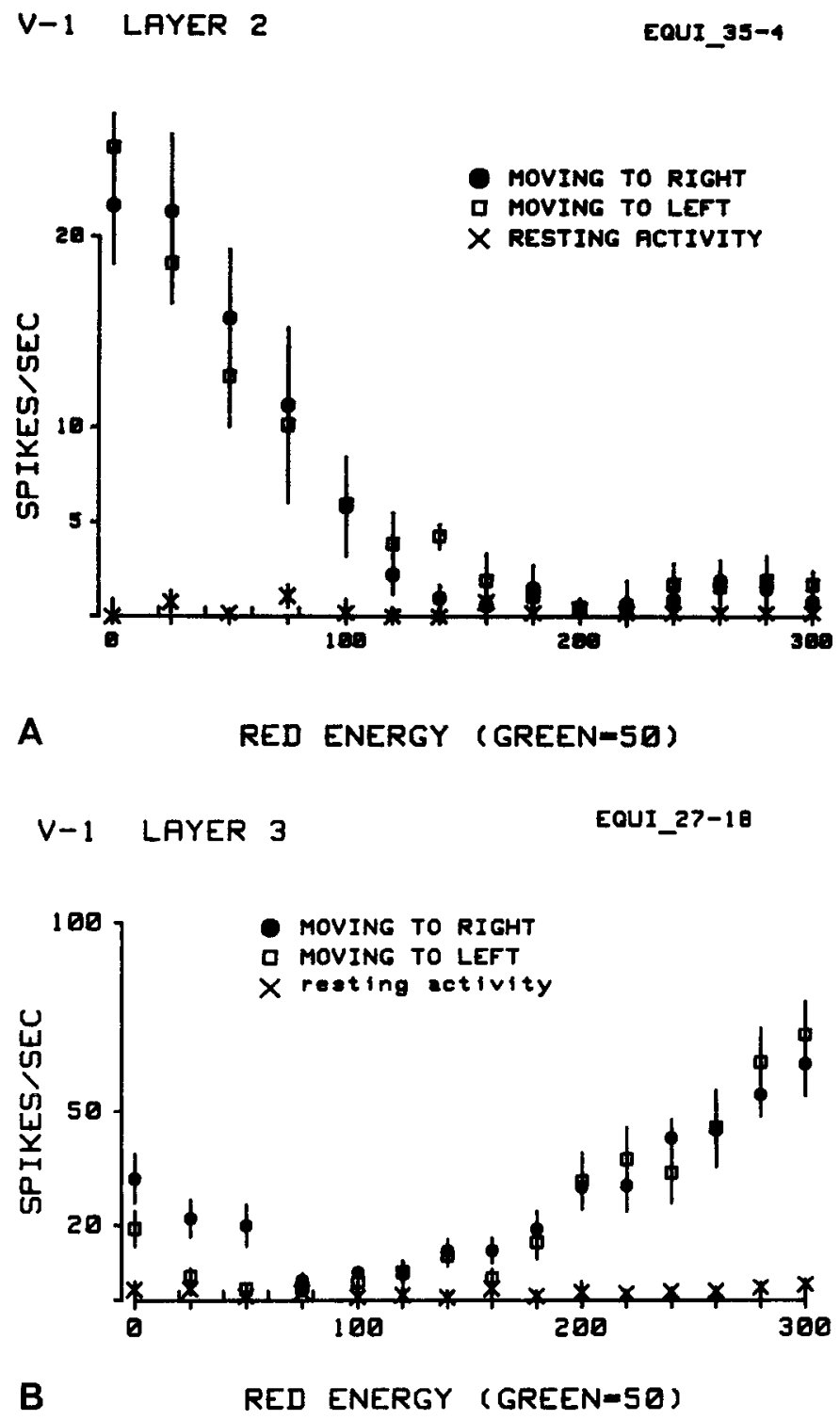

Figure 4. Cell that responds better to dark than light bars $(A)$ and the reverse, a cell that responds better to light than to dark bars $(B)$. Both from layers 2 and 3 interblob regions.

higher than the average response of $0.12 \pm 0.11$ seen in the magno-derived layers.

In making thesc observations, we were well aware of the possibility that chromatic aberration can produce artifactual luminous-contrast fringes at the edges of the bar and may therefore mask decrements in response to pure color contrast. One has only to look at a red bar on a green background through the periphery of one's -3 diopter glasses to observe a narrow but conspicuous yellow line on one side and a dark line on the other. We went to some pains to determine whether the apparent lack of a null in these cells could be due to chromatic aberration. One way of ruling out this possibility is to use sinewave gratings at 1 cycle/deg or lower (Cavanagh and Anstis, 1986). For driving cortical cells such low spatial frequency gratings are generally much less effective than well-focused dark or light bars, but they usually produce some response. We tested 43 cells with 1 cycle/ deg gratings; the results are shown as squares in Figure 7. Many cells responded almost as well to an equiluminant grating as 


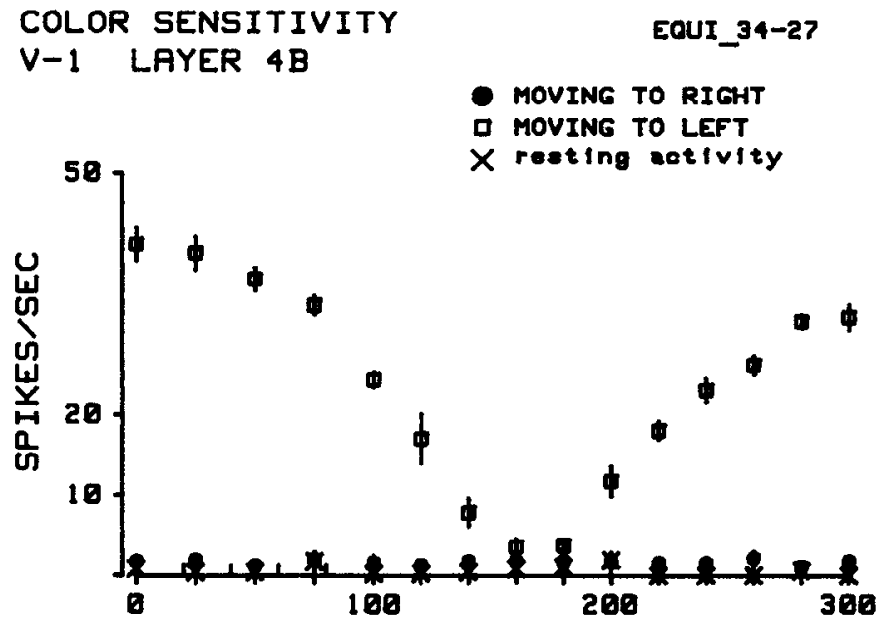

A

RED ENERGY (GREEN=5Q)
COLOR SENSITIVITY
$V-1$ LAYER 4B

- MOVING TO RIGHT

a MOVING TO LEFT

$X$ resting activity

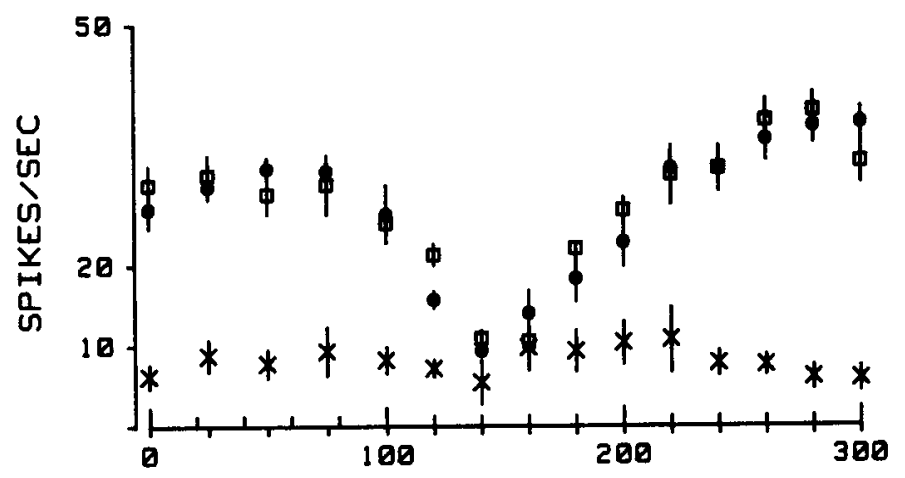

C RED ENERGY (GREEN=50)

\section{COLOR SENSITIVITY $V-1$ LAYER $4 B$}

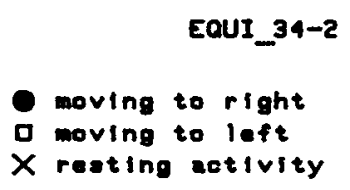

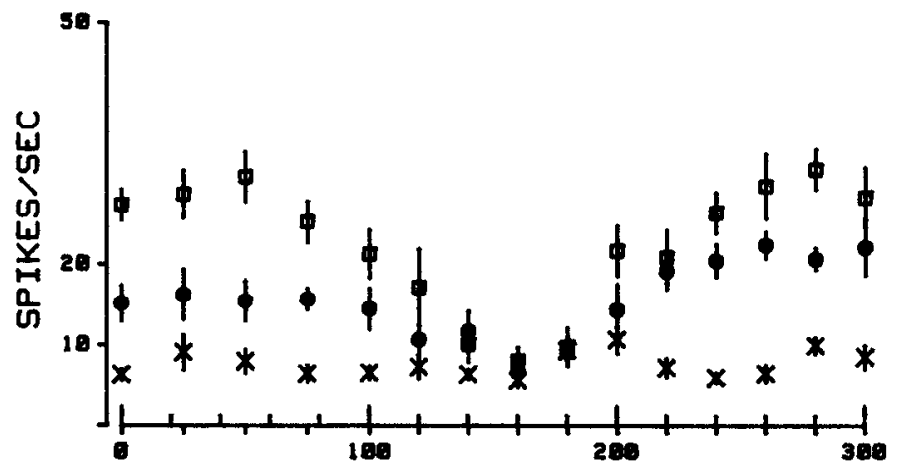

RED ENERGY (GREEN=50)

\section{V-1 LAYER 4B \\ SINEWAVE GRATING}

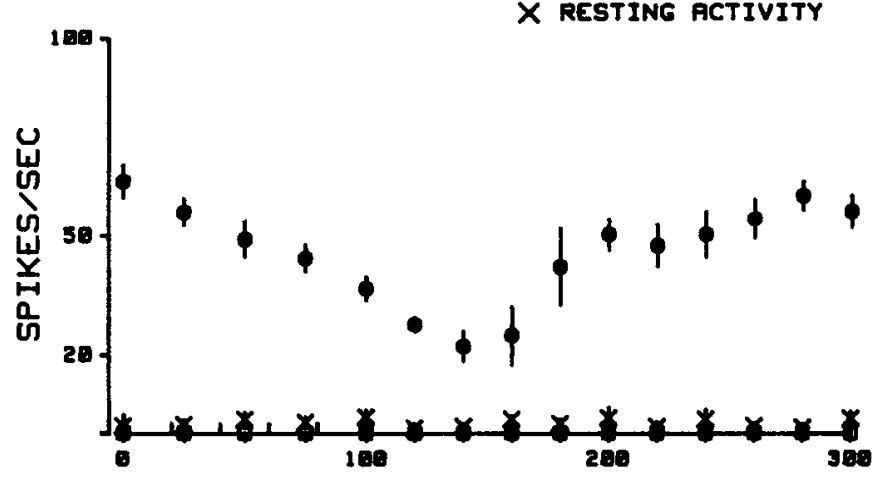

D RED ENERGY (GREEN=5Q)
EOUI_39-22

MOVING TO RIGHT

- MOVING TO LEFT

$\times$ RESTING ACTIVITY

\section{B}

Figure 5. $A-C$, Responses to a red bar of optimum orientation, size, and speed moved across the receptive field of 4 layer $4 \mathrm{~B}$ cells. The brightness of the bar was varied (red $=0-300$, green $=0$, blue $=0$ ), and the background was a steady green $($ red $=0$, green $=50$, blue $=0$ ). The cells in $A$ and $B$ are almost completely direction selective, and the cells in $C$ and $D$ were not direction selective. All 3 cells showed a minimum response near human equiluminance $(\mathrm{red}=150)$. In $D$, the stimulus was a 1 cycle/deg grating moved at 3 cycles/sec. Resting activity was measured when the grating was present but not moving. Five to 10 responses were averaged for each point.

they did to a luminance contrast grating. Twenty-four cells tested both with bar stimuli and with 1 cycle/deg sinewave gratings gave similar results with the 2 methods; one such cell is shown in Figure $6, C, D$. The average fractional response (response at equiluminance/best response) to bar stimuli was $0.47 \pm 0.18$; the average fractional response of the same 24 cells measured with sinewave gratings was $0.40 \pm 0.21$. From this it seems unlikely that chromatic aberration is causing significant artifactual responses in our experiments.

Some cortical cells do not respond well to gratings because of inhibition by multiple bars within the receptive field (Born and Tootell, 1989), so we tested some cells with blurred single bars. For 3 cells that showed no null, we interposed spherical lenses that added or subtracted 1,2, or 3 diopters, to defocus progressively the red/green edges. These lenses progressively reduced the responses at all red-to-green ratios, but the fractional response at equiluminance was the same as in the focused condition; that is, defocusing did not create a null.

We conclude, in agreement with Gouras and Krüger (1979), that many upper-layer V-1 cells that otherwise show no color selectivity respond well to chromatic red-green borders at all relative intensities.

We also used red-green bars to measure the responses of broadband unoriented blob cells. Some cells responded at all redgreen ratios, and some showed a null at equiluminance. The average fractional response of the 11 broad-band blob cells we tested was $0.22 \pm 0.15(\mathrm{SD})$.

\section{Contrast sensitivity}

We measured luminance-contrast sensitivity in the geniculate and in $\mathrm{V}-1$ by finding the contrast needed to give a half-maximal response. We preferred this over determining spikes/percent 


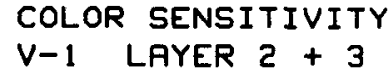

EOUI_18-3
COLOR SENSITIVITY

$V-1$ LAYERS 2,3

RED BAR, GREEN BACKGROUND moving to right

c moving to left

$x$ resting ectivity
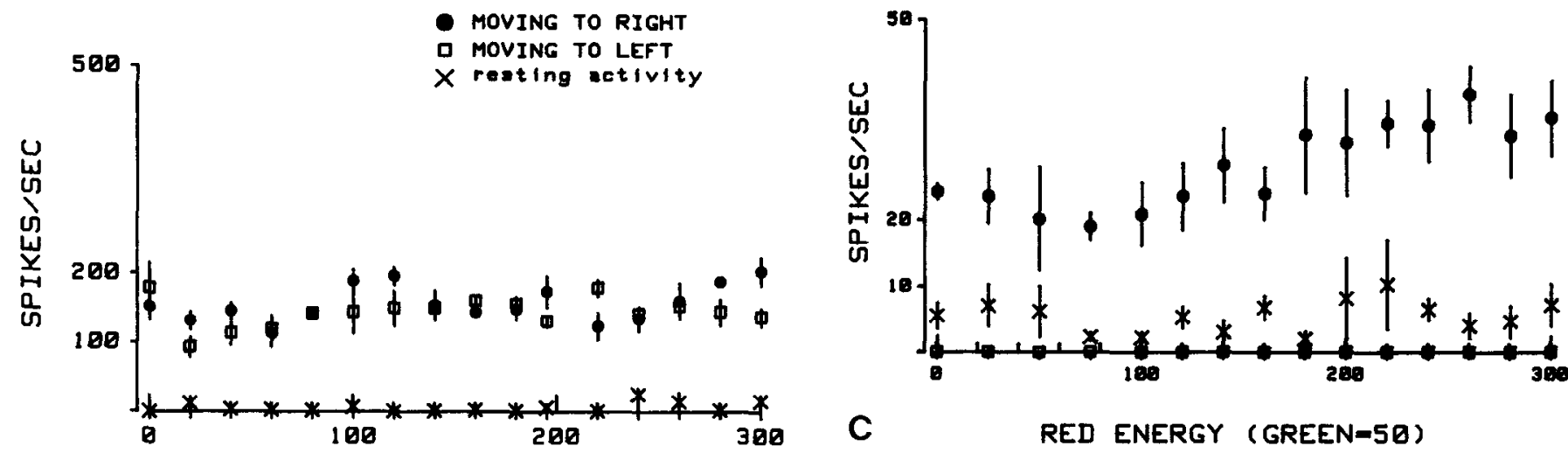

A

RED ENERGY (GREEN $=50$ )

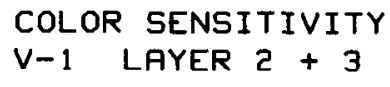

COLOR SENSITIVITY
$V-1$ LAYER $2+3$

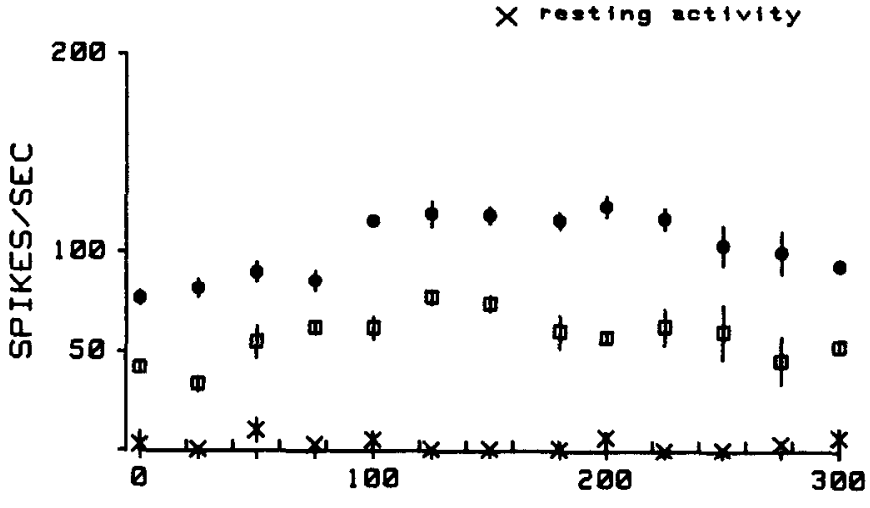

B

EOUI_11-28

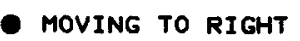

D MOVING TO LEFT
$\times$ resting activity

RED ENERGY (GREEN=50)

\author{
COLOR SENSITIVITY \\ $V-1$ LAYERS 2,3 \\ SINEWAVE GRATING
}

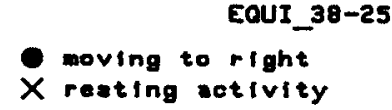

Figure 6. A-C, Responses of four layer 2 and 3 cells to a red bar of optimum orientation, size, and speed. These cells illustrate the population of layer 2 and 3 cells that do not show significant decreases in response at any color ratio. The brightness of the bar was varied against a constant green background (red $=0$, green $=50$, blue $=0$ ). Human equiluminance is at red $=150$. Panel $D$ shows the response of the same cell as in $C$ to a $1 \mathrm{cyclc} / \mathrm{deg} \mathrm{red} / \mathrm{green}$ sinewave grating moved at $3 \mathrm{cycles} / \mathrm{deg}$. This cell was unusual in that it responded as well to a grating as to a single bar. Five to ten responses were averaged for each point.

contrast, as was done by Shapley et al. (1981) and Kaplan and Shapley (1982) because we wanted our measurements to be independent of the maximum firing rate of the cell, which differs between the 2 divisions of the geniculate and even more among cells in the cortex. In the geniculate we turned on and off a small gray spot of variable intensity against a constant gray background; the spot was the same size as the receptive field center. In the cortex we measured the response to a moving variableintensity gray bar against a constant gray background.

\section{Lateral geniculate body}

Graphs of response versus contrast for 3 magnocellular neurons are shown in Figure 8 and for 2 parvocellular neurons in Figure 9. Magnocellular neurons responded well at very low contrasts, the responses reaching a maximum when the stimulus was only 2 or 3 times brighter than the background. Parvocellular neurons responded less vigorously at very low contrasts and reached their maximum response only when the stimulus was 5-10 times brighter than the background. Our results are thus very similar to those of Kaplan and Shapley (1982), even though they stimulated with sinewave gratings.

Figure 10 shows the contrast at half-maximal response for all the geniculate cells we studied. The average contrast at halfmaximal response was $3.5+2.8$ (SD) for 34 parvocellular cells, and $0.45 \pm 0.24$ (SD) for 16 magnocellular cells. Thus, the average contrast sensitivity of magnocellular neurons was much higher than that of parvocellular neurons, although a few parvocellular neurons had high contrast sensitivity. 


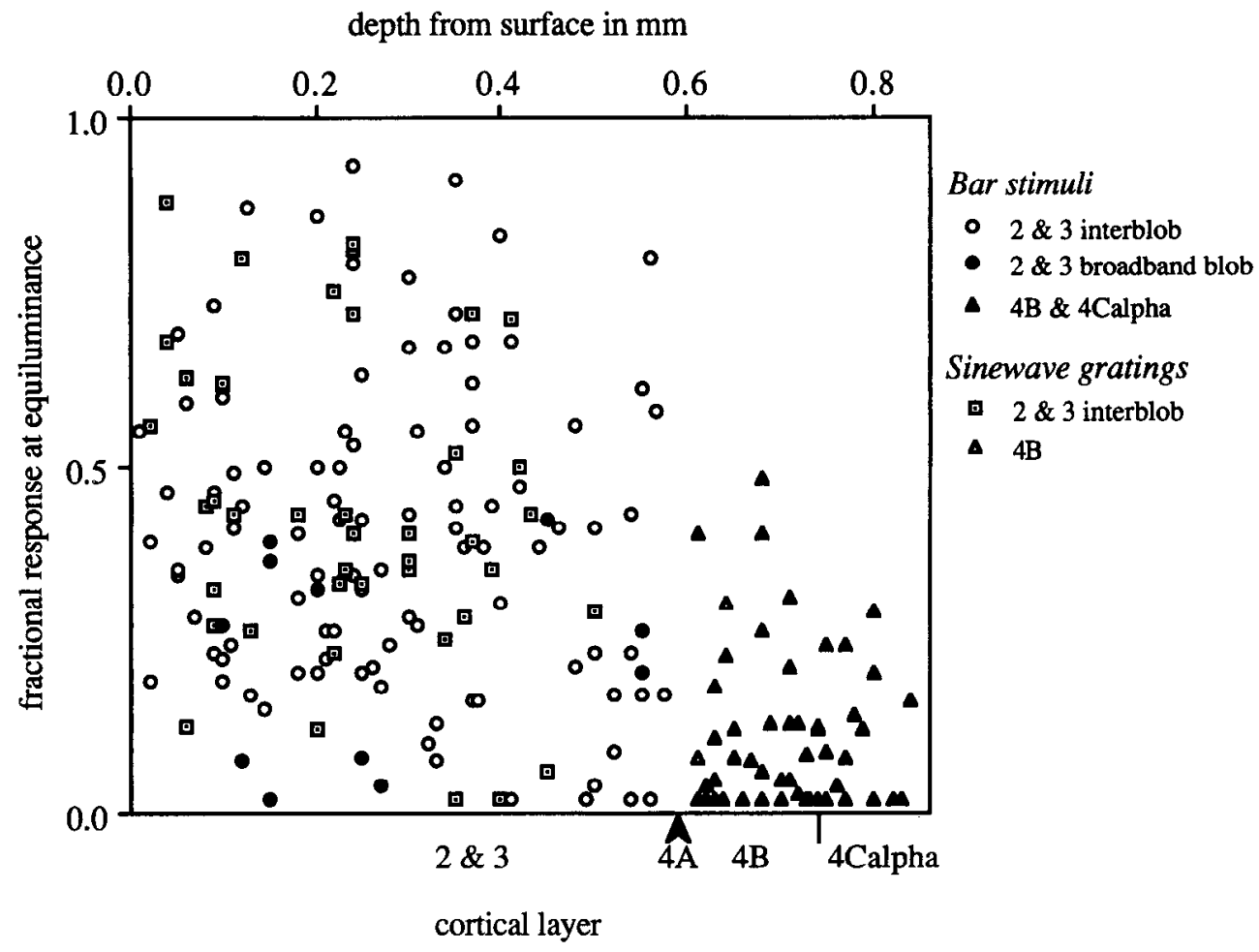

Figure 7. Fractional response at equiluminance of cells in the upper layers of $\mathrm{V}-1$ to a red bar moving on a green background (red $=0$, green $=50$, blue $=0$ ). For isolated units in 15 experiments we have plotted the response at human equiluminance ( $\mathrm{red}=140$ 160 ) as a fraction of the maximum response from graphs such as those in Figures 5 and 6.

\section{Visual area 1}

A typical graph of response as a function of contrast for an interblob cell in layer 3 is shown in Figure $11 \mathrm{~A}$ and for a layer 4B cell in Figure $11 B$. The contrast at half-maximal response for all the cortical cells we studied is shown in Figure 12. The average contrast at half-maximal response was $1.2 \pm 0.95$ (SD) for 99 upper-layer interblob cells, $1.6 \pm 0.9$ (SD) for 25 upperlayer blob cells, and $0.71 \pm 0.35$ (SD) for 46 layer $4 \mathrm{~B}$ and $4 \mathrm{C} \alpha$ cells. Thus, layer $4 \mathrm{~B}$ and $4 \mathrm{C} \alpha$ cells were slightly less sensitive than the magnocellular geniculate cells that feed them, and blob and interblob cells were on average considerably more sensitive than parvocellular geniculate cells.

\section{Binocular disparity tuned cells}

In the course of this study we tested many cells for selectivity for binocular disparity. We characterized a cell as being tuned for disparity if the binocular response was clearly different from the response to either eye alone and from the sum of the 2 responses. We saw 3 kinds of disparity tuned cells, as previously described by Poggio and Fischer (1977), luned excitatory, luned inhibitory, and near/far. In layers 2 and 3 we did not encounter any cells that were clearly disparity tuned. Though many cells responded better to binocular stimulation than to stimulation of either eye alone, the binocular response could be accounted for as a simple summation of inputs from the 2 eyes, being less than the sum of the monocular responses. The range of disparities over which the 2 eyes interacted was moreover about the same as the receptive-field width. In layer $4 B$ we found 32 cells that were clearly selective for binocular disparity. Twenty-eight of these were tuned excitatory cells. They showed a much greater binocular response than would be expected from the sum of the monocular responses, and many showed almost no response to monocular stimulation. For these cells the range of disparities over which the response peaked was much smaller than either eye's receptive field width. For a tuned excitatory cell in layer $4 \mathrm{~B}$, the disparity tuning curve is shown in Figure $13 \mathrm{~A}$. We saw 3 near/far cells, which had clearly asymmetric disparity tuning curves. Figure $13 B$ shows the disparity tuning curve of a tuned inhibitory cell in layer $4 \mathrm{~B}$; this cell was also strongly direction selective (Fig. 13C). Its color selectivity, typical for layer $4 \mathrm{~B}$, is shown in Figure $5 \mathrm{~A}$.

The lack of clear disparity-tuned cells in layers 2 and 3 was in striking contrast to their high frequency in layer $4 \mathrm{~B}$. A similar segregation is found in prestriate cortex: disparity-tuned cells are common in the thick stripes of V-2 and in MT (Zeki, 1974; Maunsell and Van Essen, 1983; Hubel and Livingstone, 1987), both of which, like layer $4 \mathrm{~B}$, are part of the magno pathway. In comparison, in what are probably the prestriate continuations of the parvo pathway, the $\mathrm{V}-2$ thin and pale stripes and $\mathrm{V}-4$, disparity-tuned cells are rare or nonexistent (Zeki, 1978; Hubel and Livingstone, 1987).

On correlating the positions of these stereo-tuned cells with the overlying cytochrome oxidase pattern in the upper layers, we found that 20 of them clearly lay beneath interblob regions. We could not determine the exact locations of the other 12 stereo-tuned cells, relative to the overlying blobs, but we saw no stereo-tuned cells that were unequivocally under blobs. We classified 17 layer 4B cells as being clearly not stereo-tuned12 of these were located under blobs, and the locations of the rest were unclear. These examples suggest that layer $4 \mathrm{~B}$ is heterogeneous, with the stereo-tuned cells selectively located under interblobs.

\section{Discussion}

One goal of this study was to examine the degree of separation of the magno- and parvocellular pathways in the upper layers of monkey striate cortex. To do this we used 2 of the distin- 


\section{CONTRAST SENSITIVITY MAGNOCELLULAR}

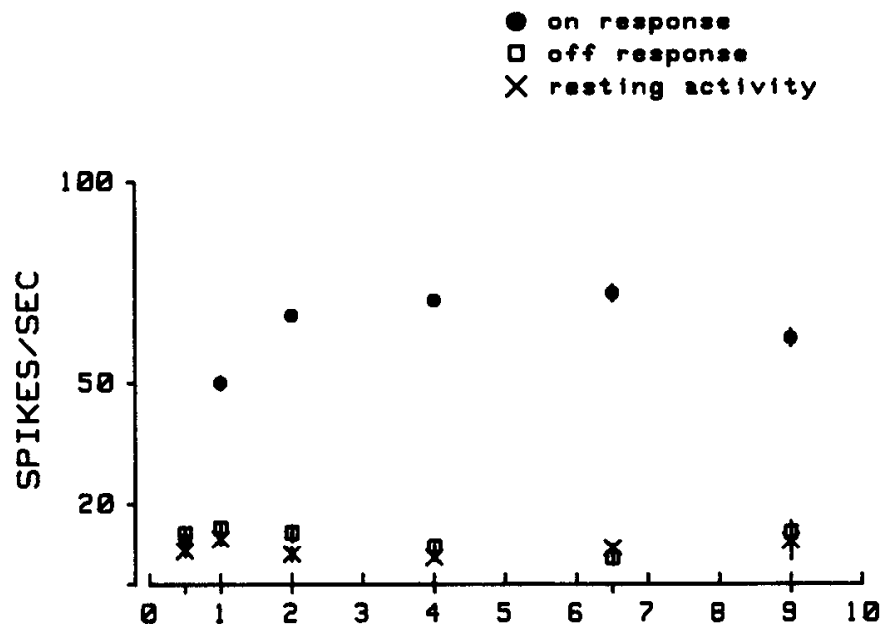

A CONTRAST--( spot-bkg) /bkg

\section{CONTRAST SENSITIVITY MAGNOCELLULAR}

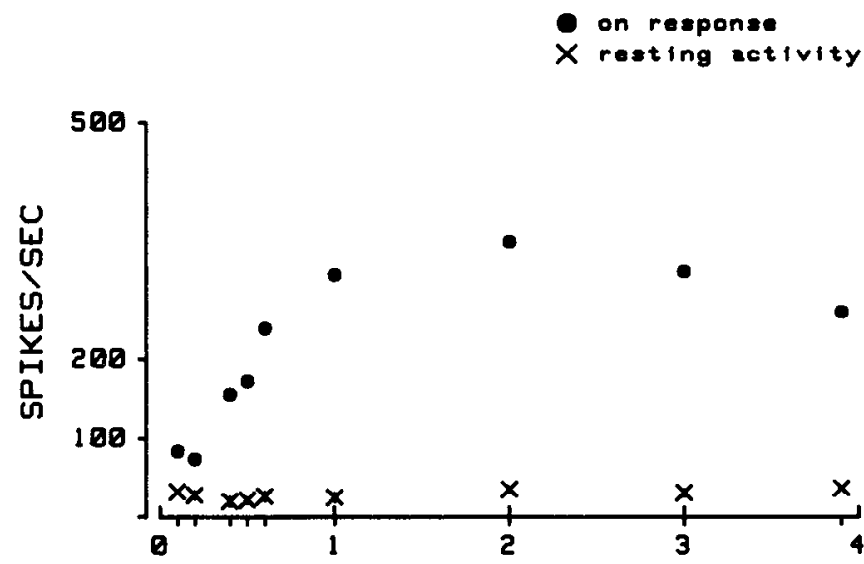

B

CONTRAST-- (spot-bkg)/bkg

EOUI 3-14

\section{CONTRAST SENSITIVITY MAGNOCELLULAR}

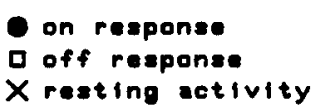

\section{CONTRAST SENSITIVITY PRRVOCELLULRR}

D off reapones

X resting activity

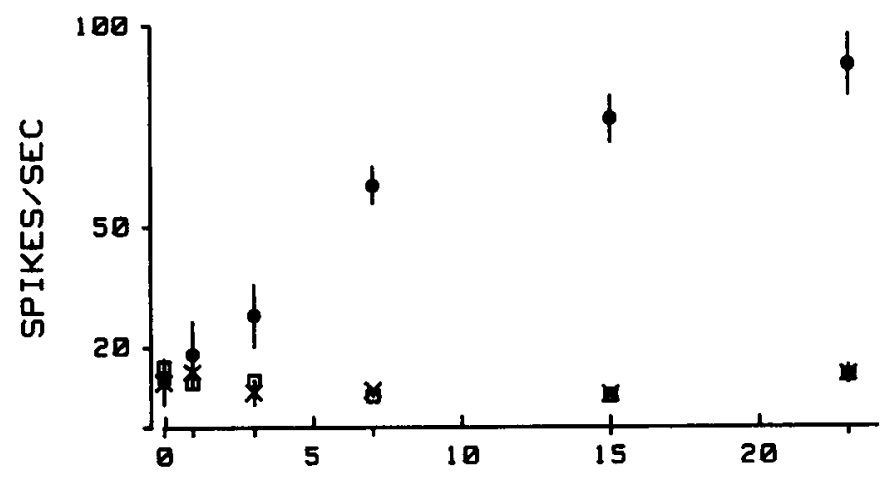

A

$$
\text { CONTRAST-- (spot-bkg)/bkg }
$$
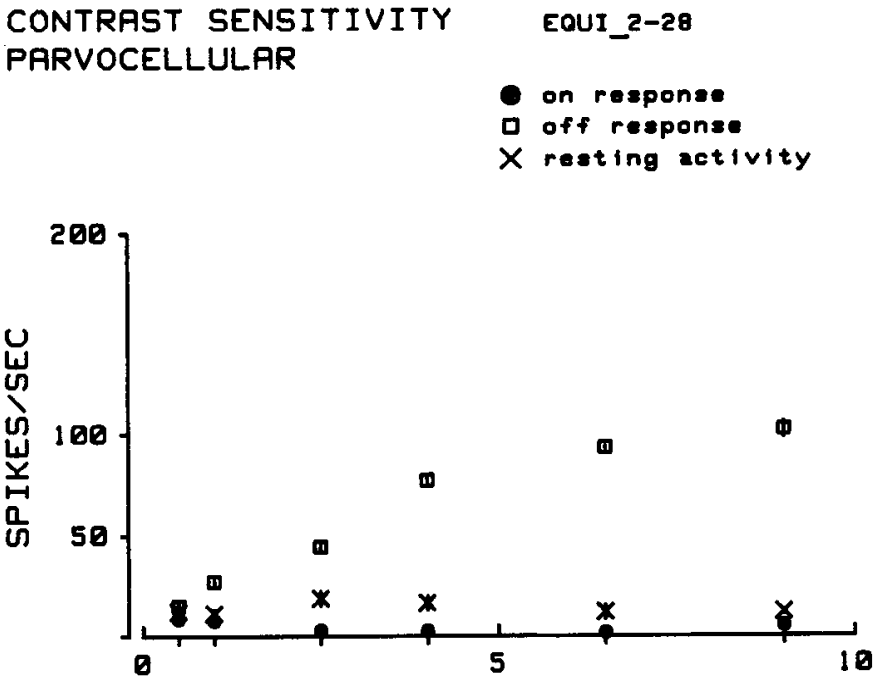

B

$$
\text { CONTRAST--(spot-bkg)/bkg }
$$

Figure 9. Responses of one broadband on-center parvocellular geniculate unit and one broadband off-center unit to a gray spot on a gray background, as a function of the contrast of the spot against the background. The stimulus parameters were the same as in Figure 7. The oncenter cell in $A$ had a receptive-field located $20^{\circ}$ from the fovea, and the off-center cell in $B 15^{\circ}$ from the fovea. Both cells had field centers $0.3^{\circ}$ in diameter, and we used a $0.3^{\circ}$ stimulus spot.

Figure 8. Responses of 3 magnocellular geniculate units to a gray spot on a gray background, as a function of the contrast of the spot against the background. The stimulus spot was turned on for $1 \mathrm{sec}$ once every $6 \mathrm{sec}$. Each point represents the average for 5-10 stimuli. The onresponse was taken for the first $250 \mathrm{msec}$ after the spot turned on, the off response is for the first $250 \mathrm{msec}$ after the spot was turned off, and the spontaneous activity for the $1 \mathrm{sec}$ interval before the stimulus was turned on. The cells in $A$ and $B$ were on-center units and the cell in $C$ was an off-center unit. For all 3 cells the receptive field center and the stimulus spot were $1 / 2^{\circ}$ in diameter. The units in $A$ and $C$ had receptive fields $15^{\circ}$ from the fovea, and the cell in $B$ was $20^{\circ}$ in eccentricity. Many magnocellular cells, like these 3 , showed smaller responses at contrasts above saturation, as previously described by Kaplan et al. (1987), who suggested it represents contrast gain control, serving to protect the cortex from premature saturation. 


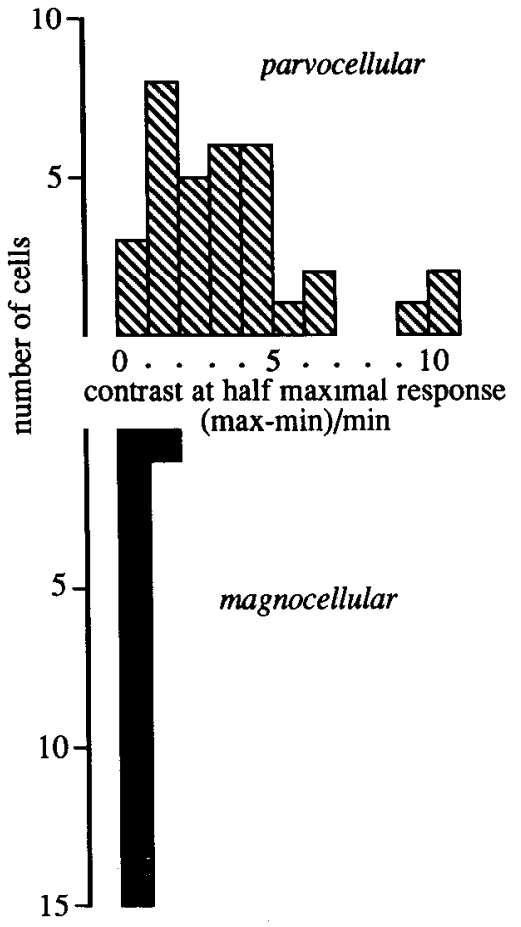

Figure 10. Contrast at half-maximal response for 34 parvocellular geniculate units and 16 magnocellular units from graphs such as those in Figures 8 and 9.

guishing differences between magno- and parvocellular geniculate cells: (1) most (but certainly not all) parvocellular cells are color opponent, whereas magnocellular cells are not (except for the red bias of the surrounds of Type 4 cells; De Valois et al., 1966, 1977; Wiesel and Hubel, 1966; Gouras, 1968, 1969; De Monasterio and Gouras, 1975; Schiller and Malpeli, 1978; Derrington et al., 1984), and (2) magno cells are much more sensitive than parvo cells to luminance contrast (Scobey, 1981; Shapley et al., 1981; Kaplan and Shapley, 1982; Derrington and Lennie, 1984; Kaplan and Shapley, 1986).

\section{Contrast sensitivity}

As cxpccted, our studies of contrast sensitivity in the lateral geniculate fully confirmed the findings of others, that contrast sensitivity cleanly distinguishes magno and parvo cells. Our assumption was that the same would be true for the cortexthat measuring the contrast sensitivity of a cell would permit us to say at once whether its input was magno, parvo, or a mixture of the two. For cells in layer $4 \mathrm{C} \alpha$ and $4 \mathrm{~B}$, the contrast sensitivity functions were indeed consistent with the anatomical evidence that the predominant input to these layers is magnocellular. Similar results in these layers have been reported by Blasdel and Fitzpatrick (1984) and Hawken et al., (1987). Deoxyglucose studies by Tootell et al. (1988) are also in agreement.

The interpretation of our results in layers 2 and 3 of striate cortex is not so simple. Consistent with the results of deoxyglucose uptake (Tootell et al., 1988), contrast sensitivities were generally lower in layers 2 and 3 than in magnorecipient layers, but the average contrast sensitivity of these cells was distinctly higher than that of parvocellular geniculate cells. This higher sensitivity may reflect a magnocellular contribution, as has been suggested anatomically (Lund and Boothe, 1975; Fitzpatrick et al., 1985) and physiologically (Malpeli et al., 1981; Blasdel and
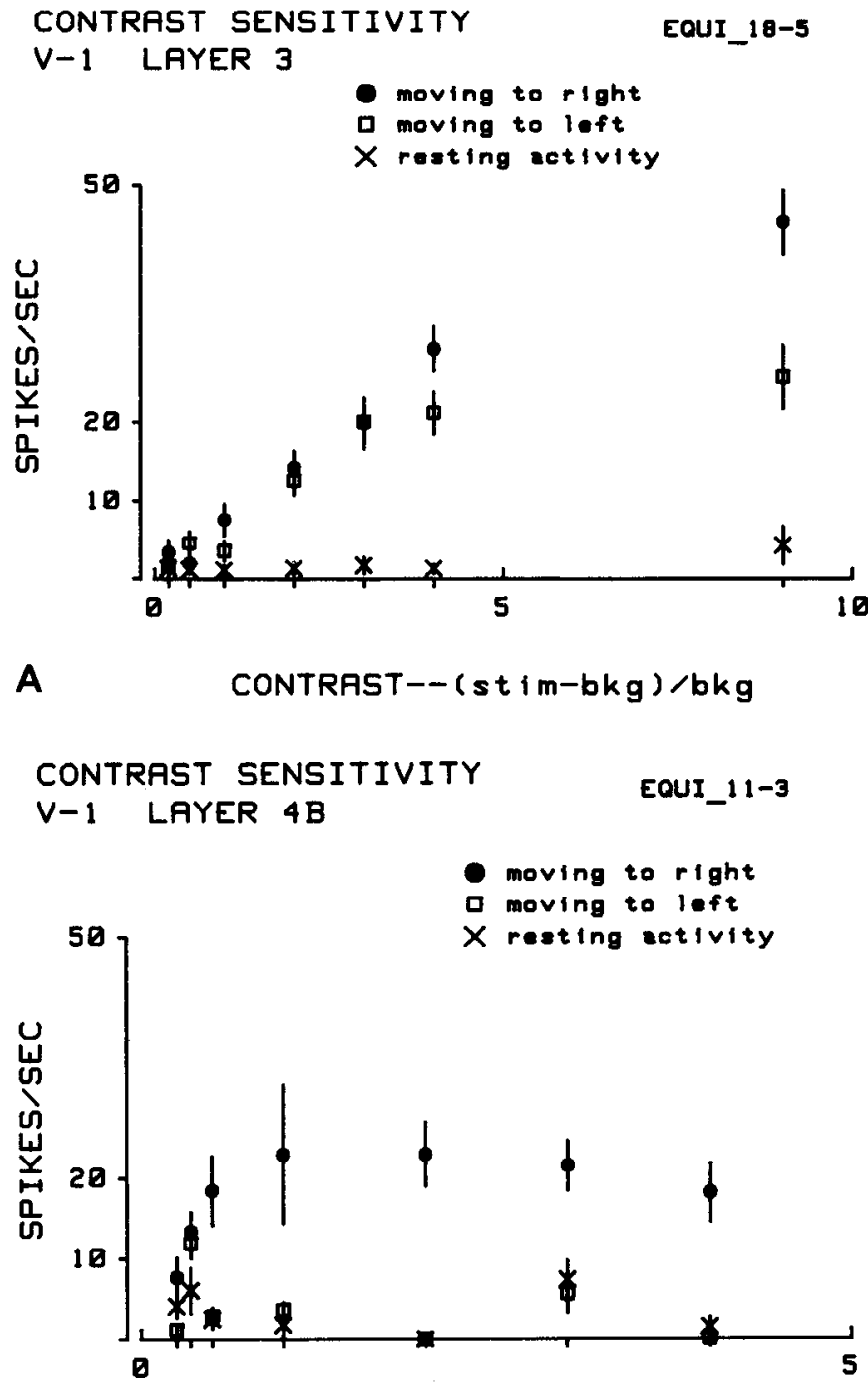

B

$$
\text { CONTRAST-- (st i m-bkg) /bkg }
$$

Figure 11. Contrast sensitivity functions of $2 \mathrm{~V}-1$ neurons. $A$, Typical interblob layer 3 cell; $B$, typical layer $4 \mathrm{~B}$ cell. Responses were measured to a gray bar of optimum orientation, size, and speed at varying contrasts against a gray background. Five responses were averaged for each point.

Fitzpatrick, 1984), but it could conceivably also result from intracortical processing: convergence of geniculate inputs onto single cells might allow enough signal averaging to enhance contrast sensitivity (Shapley and Lennie, 1985; Merigan and Eskin, 1986; Kaplan et al., 1987). If so, it is curious that no comparable enhancement occurs in layers $4 \mathrm{~B}$ or $4 \mathrm{C} \alpha$.

\section{Color selectivity}

Magnocellular receptive-field centers in the lateral geniculate receive an input of the same sign, either excitatory or inhibitory, from red and green cones; that is, they are broad band. One might therefore expect these cells to be insensitive to the alternation of 2 colors whose relative brightnesses are such that the effect of the red cones just matches that of the green cones. This was one of several lines of reasoning that prompted our hypothesis that the aspects of visual perception that deteriorate at equiluminance do so because they are carried predominantly by the magno system (Livingstone and Hubel, 1987b). 
Figure 12. Scatter plot of contrast sensitivity versus depth in V-1. Depth from the surface is indicated along the top of the graph, and the corresponding cortical layer is indicated along the bottom. The contrast at half-maximal response was determined from graphs such as those in Figure 11 for cells from the same 15 experiments as in Figure 7. By comparison with Figure 10, the average contrast sensitivity for layer 2 and 3 cells is higher than the average sensitivity for parvocellular geniculate cells.

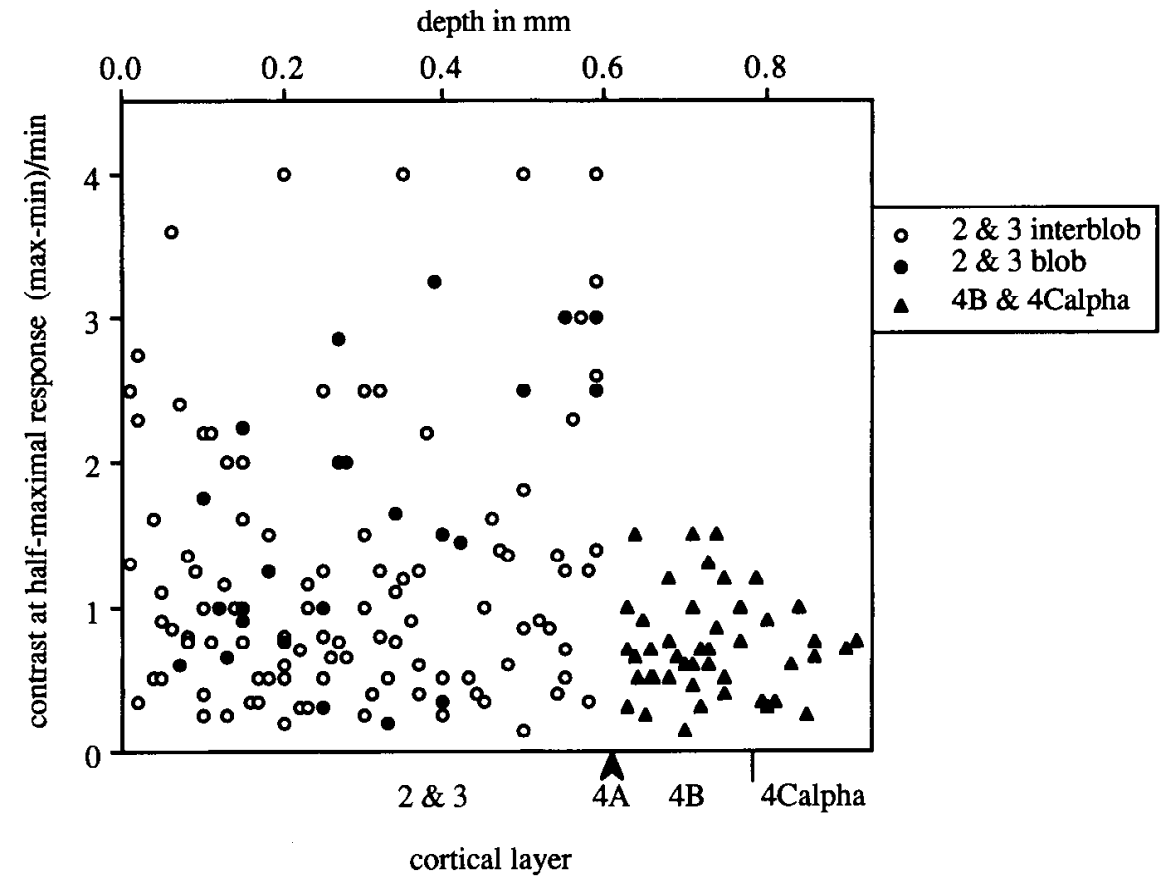

Previous work for the most part supports this idea: Krüger (1979) found that most parvocellular cells responded to moving equiluminant color borders but that magnocellular cells were generally unresponsive; Hicks et al. (1983) and Derrington et al. (1984) reported that magnoccllular cclls were less responsive to moving equiluminant sinewave gratings than parvocellular cells, but not unresponsive. On the other hand, Schiller and Colby (1983) and Hurlbert et al. (1987) have reported almost opposite results-that magnocellular cells do not show a response null to alternations of 2 colors at any relative brightness and that it is only in the parvocellular layers that cells become unresponsive at suitably chosen relative red-lo-green brightness ratios. We do find that some magnocellular cells give a brief burst at any color exchange, even at equiluminance, but in all cases the responses at or near equiluminance were less than at any other color ratio.

It has been argued (Cavanagh, 1988a) that the failure of motion perception or stereopsis to disappear completely at equiluminance indicates a chromatic-system contribution to those submodalities. We instead suspect that cells in the magno system, although fundamentally achromatic, still show some response to color-contrast borders without carrying information about the colors themselves. If magnocellular cells sum cone inputs in their receptive-field centers in a linear fashion, it should be possible to select 2 different colors that produce equivalent amounts of excitation (or inhibition). But magno cells are exquisitely sensitive to changes in contrast, and for a complete response nulling, the time course of activation in the path leading from one set of cones would have to be precisely matched by the cessation of activation in the path from the other. Any temporal adaptation (Nelson et al., 1976; Leeper and Carlton, 1985) or differences in timing between activation and cessation would also prevent a complete null, but we did not attempt to vary the exact timing.

At levels beyond the geniculate, another possible reason for a lack of complete nulling in some cells could be the small variability in the null points of magnocellular geniculate cells feeding them.

Are such frequency-doubled signals in the magno system as do get through at equiluminance in fact used for stereopsis or movement perception? Schein and Marrocco (1988) have pointed out that when a system responds to both directions of a color change, red-to-green and green-to-red, those signals cannot be useful for visual functions in which the sign of contrast is crucial. Several of the functions thought to be carried by the magno system do indeed seem to be contrast-sign specific: apparent movement appears to go in the opposite direction from image displacement if the images are contrast-rcversed (Anstis and Rogers, 1975); reversed stereo is seen with overlapping contrastreversed images (Anstis and Rogers, 1975); and inconsistent edge polarity abolishes the perception of shape-from-shading and illusory borders (Cavanagh, 1985; Cavanagh and Leclerc, 1985). Even the question of whether, psychophysically, movement perception and stereopsis are entirely lost at equiluminance is a vexed one, since technical difficulties abound, such as chromatic aberration and variations in equiluminance with eccentricity (Viénot, 1983). Whatever is left of these functions at equiluminance could be carried by the residual responses of the magno system or by an input from the parvo system.

Cavanagh (1988b) has recently presented evidence that the small amount of motion perception that remains at equiluminance is unlikely to be carried by an achromatic pathway. Thus, studies using equiluminance alone to determine whether some visual function can be ascribed to the magno or the parvo system would be inconclusive and should be coupled with information on contrast sensitivity, temporal resolution, and spatial resolution (Livingstone and Hubel, 1987b).

In the parvocellular geniculate layers, most cells did not show a response minimum at human equiluminance, but all showed a marked dip at some intensity ratio that varied widely from cell to cell. This result was hardly unexpected. About $70-80 \%$ of parvocellular cells are Type 1, with field centers supplied 


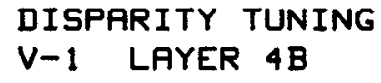

DISPARITY TUNING
$V-1$ LAYER $4 \mathrm{~B}$

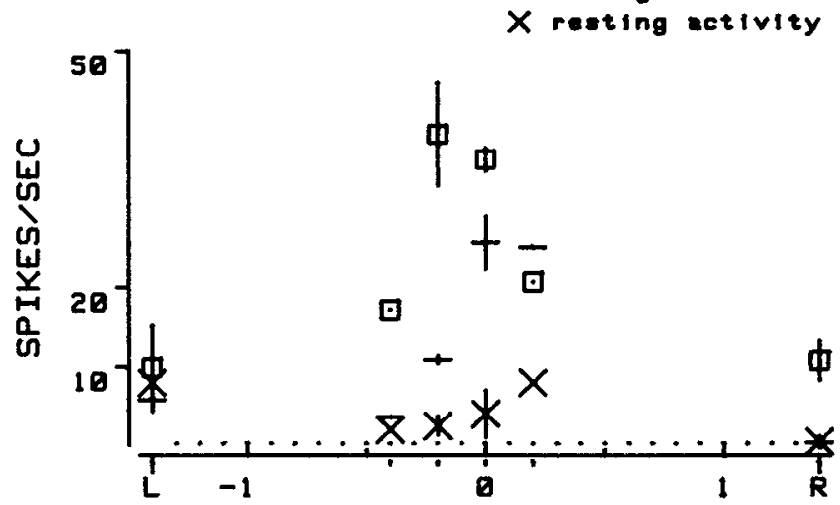

A

DISPRRITY TUNING
$V-1$ LAYER $4 B$

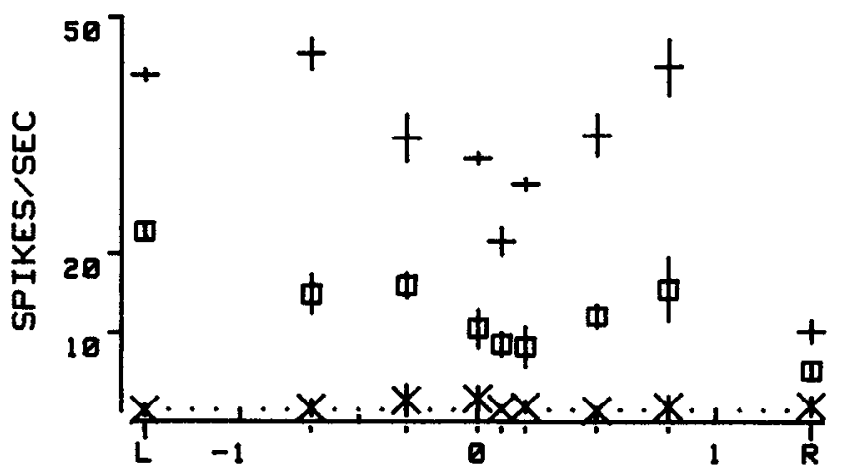

B

DISPARITY (degrees)
PRISM_5-3

申 . -

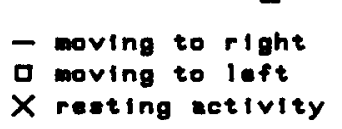


cells, and the response properties of at least somc doublc-opponent cells are consistent with color constancy. In support of this idea are hints that the Type 2 cells may be concentrated at the edges of the parvocellular layers or in the interlaminar zones (Livingstone and Hubel, 1984, and unpublished observations; Michael, 1988) and the anatomical evidence that, at least in squirrel monkeys, the interlaminar zones supply input to the blobs (Fitzpatrick et al., 1983). Nevertheless, we cannot rule out the possibility that Type 1 cells also contribute to color-opponent blob cells, as we have previously suggested (Hubel and Livingstone, 1987b).

\section{Disparity tuning}

With respect to stereopsis, the most important finding of this study was the prominence of disparity-tuned cells in layer $4 \mathrm{~B}$; the scarcity, and perhaps even absence, of such cells in layers 2 and 3 ; and the weak or absent responses at cquiluminance of the stereo-tuned cells. Much of our present knowledge of primate mechanisms of stereopsis depends on the work of Poggio and his collaborators. While their use of behavioral techniques in awake animals has made it possible to overcome the major problems of control of eye position, the desirability in a highly trained animal of recording from any one cortical site many times over long periods has made histological determination of recording sites very difficult. In our acute experiments it is difficult to measure disparity more accurately than about $1 / 4^{\circ}$, even using a foveal reference electrode (Hubel and Wiesel, 1970), but relative measurements can be much more precise, so that it is at least possible to estimate sharpness of disparity tuning, and from that to say something about the cell's probable role in stereopsis. And of course electrode track reconstruction is not a problem in a brain in which only 1 or 2 penetrations have recently been made. From the results that are available from depth estimates and track reconstructions, Poggio (1984) also has the impression that in area 17 disparity-tuned cells are mainly in layer $4 \mathrm{~B}$.

In other visual cortical regions one sees a similar striking tendency for disparity-tuned cells to occur in areas belonging to the magno system, the main examples to date being the thick stripes of V-2 (Hubel and Livingstone, 1987) and MT (Maunsell and Van Essen, 1983; Zeki, 1974). Disparity tuning is rare or absent in parvo-derived areas, such as the thin and pale stripes in V-2 and area V-4, but we would stress this less because stereo cells could be in the minority and could be grouped, and because negative evidence is in any case weak. But the physiological results nevertheless make it hard to imagine that the magnocellular system plays no part, or only a minor part, in stereopsis. The psychophysical properties of stereopsis are also mostly consistent with its being carried by the magno system (see Livingstone and Hubel, 1989b, for references). For these reasons we are puzzled by the lateral geniculate nucleus lesion experiments of Schiller et al. (1990), who found marked deficits in stereopsis after parvocellular lesions but not after magnocellular lesions.

Our observations on stereo tuning in layer $4 \mathrm{~B}$ suggest that that layer may be heterogeneous, with some regions containing cells tuned for binocular disparity and other regions not. Anatomically layer 4B does appear to be heterogeneous. First, with cytochrome oxidase staining it shows very faint dark patches, which lie directly below the dark-staining blobs in layers 2 and 3 (Livingstone and Hubel, 1982). Second, we found that cells in layer 4B that project to the thick stripes of V-2 lay in clusters that are about the same size as the blobs, although they seemed unrelated to the ovcrlying blob pattcrn (Livingstonc and Hubcl, 1987a). Lastly, Zeki and Shipp (1988) found that the cells in 4B that project to prestriate area MT also lie in blob-size clusters, which similarly showed no clear relationship to the overlying blobs. The possible relationship between the stereo tuning of $4 \mathrm{~B}$ cells and the overlying blob pattern may reflect some relationship between stereo tuning and ocular dominance, and hence may be related only indirectly to the blobs, which tend to lie in the centers of ocular dominance columns (Horton and Hubel, 1981). It would not be surprising if strongly monocular cells were less important than binocular cells for stereopsis.

\section{References}

Anstis SM, Rogers BJ (1975) Illusory reversal of depth and movement during changes of contrast. Vision Res 15:957--961.

Blasdel GG, Fitzpatrick D (1984) Physiological organization of layer 4 in macaque striate cortex. J Neurosci 4:880-895.

Blasdel GG, Lund JS (1983) Termination of afferent axons in macaque striate cortex. J Neurosci 3:1389-1413.

Born RT, Tootell RBH (1989) Spatial frequency tuning and surround inhibition of single cells in macaque supragranular striate cortex. Invest Ophthalmol Vis Sci Suppl 30:111.

Cavanagh P (1985) Subjective contours signaled by luminance, vetoed by motion or depth. Bull Psychonom Soc 23:273.

Cavanagh P (1988a) Pathways in early vision. In: Computational processes in human vision: an interdisciplinary perspective (Pylyshyn $Z$, ed), New Jersey: Ablex.

Cavanagh $P$ (1988b) Interunit variability of equiluminance points does not mediate the contribution of color to motion. Invest Ophthalmol Vis Sci Suppl 29:327.

Cavanagh P, Anstis SM (1986) Do opponent-color channels contribute to motion? Invest Ophthalmol Vis Sci Suppl 27:291.

Cavanagh P, Leclerc Y (1985) Shadow constraints. Invest Ophthalmol Vis Sci Suppl 26:282.

De Monasterio FM, Gouras P (1975) Functional properties of ganglion cells of the rhesus monkey retina. J Physiol (Lond) 251:167-195.

Derrington AM, Lennie P (1984) Spatial and temporal contrast sensitivities of neurones in lateral geniculate nucleus of macaque. J Physiol (Lond) 357:219-240.

Derrington AM, Krauskopf J, Lennie P (1984) Chromatic mechanisms in lateral geniculate nucleus of macaque. J Physiol (Lond) 357:241265.

De Valois RL, Abramov I, Jacobs GH (1966) Analysis of response patterns of LGN cells. J Opt Soc Am 56:966-977.

De Valois RL, Morgan HC, Polson MC, Mead WR, Hull EM (1974) Psychophysical studies of monkey vision. I. Macaque luminosity and color vision tests. Vision Res 14:53-67.

De Valois RL, Snodderly DM, Yund EW, Hepler NK (1977) Responses of macaque lateral geniculate cells to luminance and color figures. Sens Processes 1:244-259.

Fitzpatrick D, Itoh K, Diamond IT (1983) The laminar organization of the lateral geniculate body and the striate cortex in the squirrel monkey (Saimiri sciureus). J Neurosci 3:673-702.

Fitzpatrick D, Lund JS, Blasdel GG (1985) Intrinsic connections of macaque striate cortex: afferent and efferent connections of lamina 4C. J Neurosci 5:3329-3349.

Gouras P (1968) Identification of cone mechanisms in monkey ganglion cells. J Physiol (Lond) 199:533-547.

Gouras P (1969) Antidromic responses of orthodromically identified ganglion cells in monkey retina. J Physiol (Lond) 204:407-419.

Gouras P, Krüger J (1979) Responses of cells in foveal visual cortex of the monkey to pure color contrast. J Neurophysiol 42:850-860.

Hawken MJ, Parker AJ, Lund JS (1987) Contrast sensitivity and laminar distribution of direction selective neurons in monkey striate cortex. Invest Ophthalmol Vis Sci (Suppl) 28:197.

Hendrickson AE, Wilson JR, Ogren MP (1978) The neuroanatomical organization of pathways between dorsal lateral geniculate nucleus and visual cortex in old and new world primates. J Comp Neurol 182:123-136.

Hicks TP, Lee BB, Vidyasagar TR (1983) The responses of cells in macaque lateral geniculate nucleus to sinusoidal gratings. J Physiol (Lond) 337:183-200. 
Horton JC, Hubel DH (1981) A regular patchy distribution of cytochrome-oxidase staining in primary visual cortex of the macaque monkey. Nature 292:762-764.

Hubel DH (1959) Single unit activity in striate cortex of unrestrained cats. J Physiol (Lond) 147:226-238.

Hubel DH, Livingstone MS (1987) Segregation of form, color, and stereopsis in primate area 18. J Neurosci 7:3378-3415.

Hubel DH, Wiesel TN (1970) Cells sensitive to binocular depth in area 18 of the macaque monkey cortex. Nature 225:41-42

Hubel DH, Wiesel TN (1972) Laminar and columnar distribution of geniculocortical fibers in the macaque monkey. J Comp Neurol 146: $421-450$

Hurlbert AC, Logothetis NK, Charles ER, Schiller PH (1987) The processing of color and luminance information in monkeys. Soc Neurosci Absir 13:204.

Kaplan E, Shapley RM (1982) X and Y cells in the lateral geniculate nucleus of the macaque monkey. J Physiol (Lond) 330:125-143.

Kaplan E, Shapley RM (1986) The primate retina contains two types of ganglion cells, with high and low contrast sensitivity. Proc Natl Acad Sci USA 83:2755-2757.

Kaplan E, Purpura K, Shapley RM (1987) Contrast affects the transmission of visual information through the mammalian lateral geniculate nucleus. J Physiol (I ond) 391:267-288.

Krüger J (1979) Responses to wavelength contrast in the afferent visual systems of the cat and the rhesus monkey. Vision Res 19:1351-1358.

Lee BB, Martin PR, Valberg $\Lambda$ (1989) Nonlinear summation of Mand $\mathrm{L}$-cone inputs to phasic retinal ganglion cells of the macaque. $J$ Neurosci 9:1433-1442.

Leeper HF, Carlion JS (1985) Response properties of horizontal cells and photoreceptor cells in the retina of the tree squirrel, Sciurus carolinensis. J Neurophysiol 54:1157-1166.

Leventhal AG, Rodieck RW, Dreher B (1981) Retinal ganglion cell classes in the Old World monkey: morphology and central projections. Science 213:1139-1142.

Livingstone MS, Hubel DH (1982) Thalamic inputs to cytochrome oxidase-rich regions in monkey visual cortex. Proc Natl Acad Sci USA 79:6098-6101.

Livingstone MS, Hubel DH (1984) Anatomy and physiology of a color system in the primate visual cortex. J Neurosci 4:309-356.

Livingstone MS, Hubel DH (1987a) Connections between layer $4 \mathrm{~B}$ of area 17 and thick cytochrome oxidase stripes of area 18 in the squirrel monkey. J Neurosci 17:3371-3377.

Livingstone MS, Hubel DH (1987b) Psychophysical evidence for separate channels for the perception of form, color, movement, and depth. J Neurosci 7:3416-3468.

Logothetis NK, Schiller PH, Charles ER, Hurlbert AC (1990) Perceptual deficits and the activity of the color-opponent and broad-band pathways at isoluminance. Science 247:214-217.

Lund JS (1973) Organization of neurons in the visual cortex, area 17, of the monkey (Macaca mulatta). J Comp Neurol 147:455-475.

Lund JS (1987) Local circuit neurons of macaque monkey striate cortex. I. Neurons of laminae 4C and 5A. J Comp Neurol 257:6092.

Lund JS, Boothe RG (1975) Interlaminar connections and pyramidal neuron organization in the visual cortex, area 17 , of the macaque monkey. J Comp Neurol 159:305-334.

Lund JS, Lund RD, Hendrickson AE, Bunt AH, Fuchs AF (1975) The origin of efferent pathways from the primary visual cortex, area 17 , of the macaque monkey as shown by retrograde transport of horseradish peroxidase. J Comp Neurol 164:287-304.

Malpeli JG, Schiller PH, Colby CL (1981) Response properties of single cells in monkey striate cortex during reversible inactivation of individual lateral geniculate laminae. J Neurophysiol 46:1102-1119.

Maunsell JHR, Van Essen DC (1983) Functional properties of neurons in middle temporal visual area of the macaque monkey. II. Binocular interactions and sensitivity to binocular disparity. J Neurophysiol 49 : $1148-1167$

Merigan WH, Eskin TA (1986) Spatio-temporal vision of macaques with severe loss of $P_{\beta}$ retinal ganglion cells. Vision Res 26:1751-1761.

Michael CR (1988) Retinal afferent arborization patterns, dendritic field orientations, and the segregation of function in the lateral geniculate nucleus of the monkey. Proc Natl Acad Sci USA 85:4914 4918.

Nelson R, Kolb H, Famiglietti EV Jr, Gouras P (1976) Neural responses in the rod and cone system of the cat retina: intracellular records and procion stains. Invest Ophthalmol 15:946-953.

Nunn BJ, Schnapf JL, Baylor DA (1984) Spectral sensitivity of single cones in the retina of Macaca fascicularis. Nature 309:264-266.

Poggio GF (1984) Processing of stereoscopic information in primate visual cortex. In: Dynamic aspects of neocortical function (Edelman GM, Gall WE, Cowan WM, eds), pp 613-636. New York: Wiley.

Poggio GF, Fischer B (1977) Binocular interaction and depth sensitivity in striate and prestriate cortex of behaving rhesus monkey. $J$ Neurophysiol 40:1392-1405.

Schein SJ, Marrocco T (1988) Perceptual failures at isoluminance are due to balance of on- and off-center activity. Invest Ophthalmol Vis Sci 29:296.

Schiller PH, Colby C (1983) The responses of single cells in the lateral geniculate nucleus of the rhesus monkey to color and luminance contrast. Vision Res 23:1631-1641.

Schiller PH, Malpeli JG (1978) Functional specificity of lateral geniculate nucleus laminae of the rhesus monkey. J Neurophysiol 41:788797.

Schiller PH, Logothetis NK, Charles ER (1990) Functions of the colour-opponent and broad-band channels of the visual system. Nature 343:68-70.

Scobey RP (1981) Movement sensitivity of retinal ganglion cells in monkey. Vision Res 21:181-190.

Shapley R, Lennie P (1985) Spatial frequency analysis in the visual system. Annu Rev Neurosci 8:547-583.

Shapley RM, Kaplan E, Soodak R (1981) Spatial summation and contrast sensitivity of $X$ and $Y$ cells in the lateral geniculate nucleus of the macaque. Nature 292:543-545.

Smith VC, Pokorny J (1986) Colorimetry and color discrimination. In: Handbook of perception and human performance, Vol 1, Sensory processes and perception (Boff KR, Kaufman L, Thomas JP, eds). New York: Wiley.

Thorell LG, De Valois RL, Albrecht DG (1984) Spatial mapping of monkey V1 cells with pure color and luminance stimuli. Vision Res 24:751-769.

Tootell RBH, Hamilton SL, Switkes E (1988) Functional anatomy of macaque striate cortex. IV: contrast and magno-parvo streams. J Neurosci 8:1594-1609.

Viénot $F$ (1983) Can variation in macular pigment account for the variation of colour matches with retinal position? In: Colour vision: physiology and psychophysics (Mollon J, Sharpe RT, eds), pp 107116. London: Academic.

Wiesel TN, Hubel DH (1966) Spatial and chromatic interactions in the lateral geniculate body of the rhesus monkey. J Ncurophysiol 29: $1115-1156$.

Wong-Riley MTT (1979) Changes in the visual system of monocularly sutured or enucleated cats demonstrable with cytochrome oxidase histochemistry. Brain Res 171:11-28.

Zeki SM (1974) Cells respond to changing image size and disparity in the cortex of the rhesus monkey. J Physiol (Lond) 242:827-841.

Zeki SM (1978) Uniformity and diversity of structure and function in rhesus monkey prestriate cortex. J Physiol (Lond) 277:273-290.

Zeki S, Shipp S (1988) The functional logic of cortical connections. Nature 335:311-317. 